\title{
Circulation and transport of water masses in the Lazarev Sea, Antarctica, during summer and winter 2006
}

\author{
Boris Cisewski ${ }^{\mathrm{a}, \mathrm{b}, *}$, Volker H. Strass ${ }^{\mathrm{a}}$, Harry Leach ${ }^{\mathrm{c}}$ \\ ${ }^{a}$ Alfred-Wegener-Institut für Polar- und Meeresforschung, P.O. Box 120161, 27515 Bremerhaven, Germany \\ ${ }^{\mathrm{b}}$ Institut für Umweltphysik, Abteilung Ozeanographie, Universität Bremen, P.O. Box 330440, 28334 Bremen, Germany \\ ${ }^{\mathrm{c}}$ Department of Earth and Ocean Sciences, University of Liverpool, Liverpool L69 3GP, UK
}

\section{A R T I C L E I N F O}

\section{Article history:}

Received 6 July 2010

Received in revised form

20 November 2010

Accepted 2 December 2010

Available online 5 December 2010

\section{Keywords:}

Weddell Gyre

Lazarev Sea

Geostrophy

Circulation

Transports

ADCP

\begin{abstract}
A B S T R A C T
The distribution and circulation of water masses in the region between $6^{\circ} \mathrm{W}$ and $3^{\circ} \mathrm{E}$ and between the Antarctic continental shelf and $60^{\circ} \mathrm{S}$ are analyzed using hydrographic and shipboard acoustic Doppler current profiler (ADCP) data taken during austral summer 2005/2006 and austral winter 2006. In both seasons two gateways are apparent where Warm Deep Water (WDW) and other water masses enter the Weddell Gyre through the Lazarev Sea: (a) a probably topographically trapped westward, then southwestward circulation around the northwestern edge of Maud Rise with maximum velocities of about $20 \mathrm{~cm} \mathrm{~s}^{-1}$ and (b) the Antarctic Coastal Current (AntCC), which is confined to the Antarctic continental shelf slope and is associated with maximum velocities of about $25 \mathrm{~cm} \mathrm{~s}^{-1}$.

Along two meridional sections that run close to the top of Maud Rise along $3^{\circ} \mathrm{E}$, geostrophic velocity shears were calculated from CTD measurements and referenced to velocity profiles recorded by an ADCP in the upper $300 \mathrm{~m}$. The mean accuracy of the absolute geostrophic velocity is estimated at $\pm 2 \mathrm{~cm} \mathrm{~s}^{-1}$. The net baroclinic transport across the $3^{\circ} \mathrm{E}$ section amounts to 20 and $17 \mathrm{~Sv}$ westward for the summer and winter season, respectively. The majority of the baroclinic transport, which accounts for $\sim 60 \%$ of the total baroclinic transport during both surveys, occurs north of Maud Rise between $65^{\circ}$ and $60^{\circ} \mathrm{S}$.

However, the comparison between geostrophic estimates and direct velocity measurements shows that the circulation within the study area has a strong barotropic component, so that calculations based on the dynamic method underestimate the transport considerably. Estimation of the net absolute volume transports across $3^{\circ} \mathrm{E}$ suggests a westward flow of $23.9 \pm 19.9 \mathrm{~Sv}$ in austral summer and $93.6 \pm 20.1 \mathrm{~Sv}$ in austral winter. Part of this large seasonal transport variation can be explained by differences in the gyrescale forcing through wind stress curl.
\end{abstract}

(c) 2010 Elsevier Ltd. All rights reserved.

\section{Introduction}

The Weddell Sea is an important region for the formation of Antarctic Bottom Water (AABW), which is the densest of the water masses involved in the thermohaline circulation of the world ocean (Lynn and Reid, 1968). The circulation of the Weddell Sea is dominated by the mainly wind-driven, cyclonic Weddell Gyre that controls the large-scale ocean circulation extending from the Antarctic Peninsula eastward to approximately $20-30^{\circ} \mathrm{E}$ and covering both the Weddell and Enderby Basins (Deacon, 1979; Gouretski and Danilov, 1993; Orsi et al., 1993). The southern and western boundaries of the gyre are aligned with the continental margin of Antarctica and the Antarctic Peninsula. The ridge system north of $55^{\circ} \mathrm{S}$, which consists of the South Scotia, North Weddell and Southwest Indian Ridge, bounds the Weddell-Enderby Abyssal Plain to the north

\footnotetext{
* Corresponding author at: Alfred-Wegener-Institut für Polar- und Meeresforschung, P.O. Box 120161, 27515 Bremerhaven, Germany. Tel.: +494714831 1816; fax: +494714831 1797 .

E-mail address: Boris.Cisewski@awi.de (B. Cisewski).
}

(Fig. 1a). The northern limb of the Weddell Gyre is dominated by eastward flow that joins the Antarctic Circumpolar Current (ACC). The broad easternmost limb of the Weddell Gyre between about longitudes $10^{\circ} \mathrm{W}$ and $40^{\circ} \mathrm{E}$, where the ACC is deflected southward, is where Circumpolar Deep Water (Gordon, 1967) enters the Weddell Gyre (Deacon, 1979; Bagriantsev et al., 1989; Gouretski and Danilov, 1993; Orsi et al., 1993; Schröder and Fahrbach, 1999) through the Lazarev Sea. On its course through the eastern limb this deep water mass is raised from about $1000 \mathrm{~m}$ depth in the ACC to about $400 \mathrm{~m}$ depth in the Lazarev Sea due to Ekman suction in the Antarctic Divergence and the insertion of deep and bottom waters below and is then called Warm Deep Water (Foster and Carmack, 1976).

A striking bathymetric feature of the Lazarev Sea is the Maud Rise seamount, which rises from the relatively flat surrounding abyssal plain at a depth of greater than $5000 \mathrm{~m}$ to within $1600 \mathrm{~m}$ of the sea surface. The horizontal distribution of the temperature maximum indicates an anticyclonic circulation of warm WDW over the northern and western flanks of Maud Rise (Bersch et al., 1992; Gordon and Huber, 1995; Muench et al., 2001; de Steur et al., 2007), which surrounds the seamount as a "Halo" (Gordon and Huber, 1990; Muench et al., 2001), whereas an isolated 
a

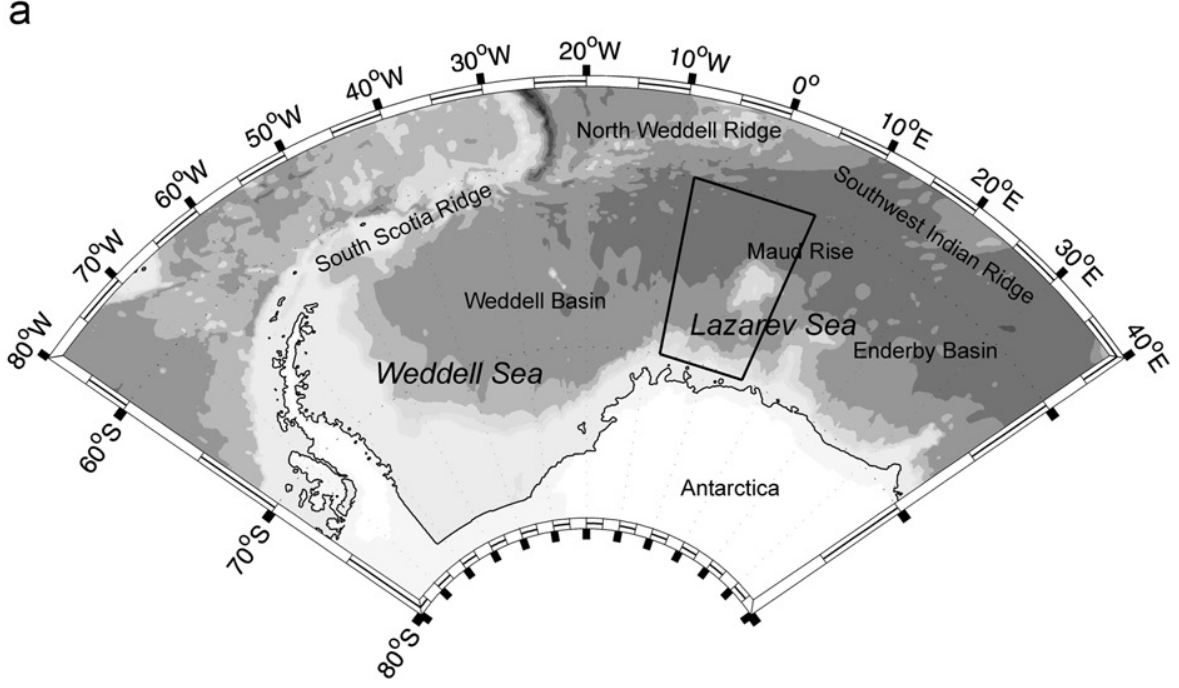

b

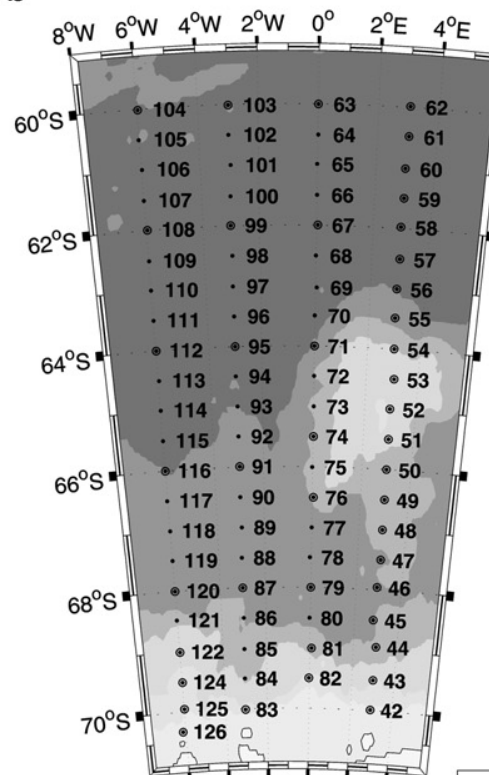

C

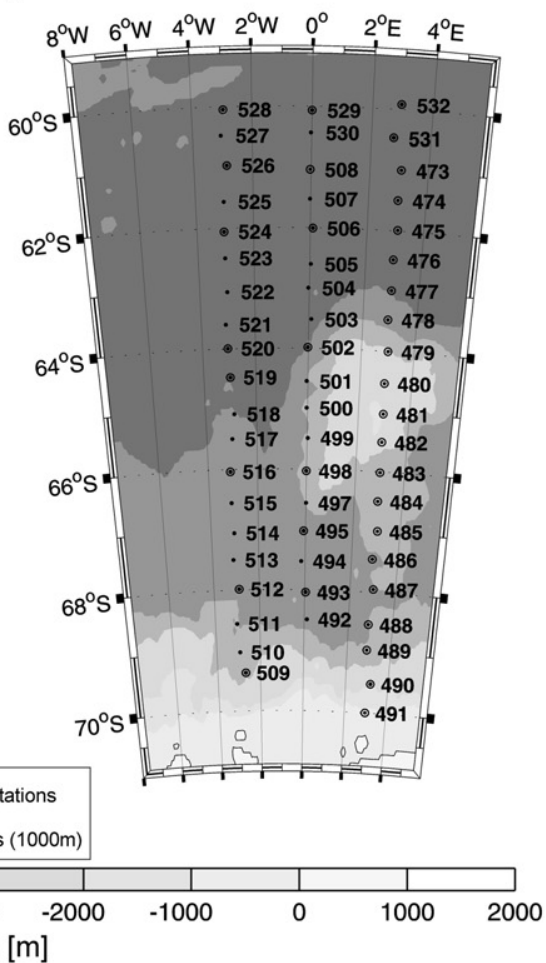

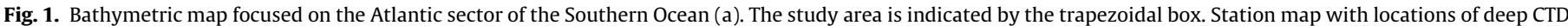

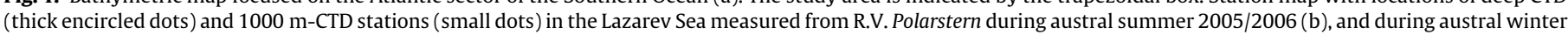
2006 (c). The depth contours (in meters) are taken from the General Bathymetric Chart of the Oceans (GEBCO) bathymetry.

Taylor column of colder and less saline water overlies the top of the rise. After advection of WDW along the northern flank of Maud Rise, shedding of eddies with WDW appears to contribute to quasi-stationary warm pools west of Maud Rise (Bersch et al., 1992; Gordon and Huber, 1995). These warm pools can lead to large upward heat fluxes and a consequent loss of pack ice (McPhee et al., 1996; Muench et al., 2001; Sirevaag et al., 2010). A second possible route for advection of water masses through the Lazarev Sea is the Antarctic Coastal Current (AntCC), which is confined to the Antarctic continental shelf. As a part of the southern limb of the Weddell Gyre, the offshore part of the AntCC carries fractions of WDW to the southwestern Weddell Sea. On its course the WDW is modified by mixing with Winter Water before it intrudes on to the shelf. This modified Warm Deep Water then mixes with High Salinity Shelf Water to form
Weddell Sea Deep Water (WSDW) or Weddell Sea Bottom Water (WSBW) (Foster and Carmack, 1976), a precursor of the Antarctic Bottom Water. Although the large-scale circulation of the Weddell Gyre is well known from the distribution of various water mass characteristics (e.g. Deacon, 1979; Gouretski and Danilov, 1993; Orsi et al., 1993; Fahrbach et al., 1994), a lack of knowledge concerning absolute velocities, their temporal variability and spatial structures, even in the southeastern limb still exists. Previous estimates of the Weddell Gyre transport varied from $17 \mathrm{~Sv}$ (Whitworth and Nowlin, 1987) to $97 \mathrm{~Sv}$ (Carmack and Foster, 1975) depending on the method chosen.

The main purpose of this paper is the investigation of the hydrographic structure, circulation and transport of the southern limb of the Weddell Gyre in the eastern inflow region of the Weddell Sea. In this 
study, we present the results of two hydrographic surveys, performed during austral summer 2005/2006 and austral winter 2006 as part of the Lazarev Sea Krill Study (LAKRIS). These surveys cover the area between $6^{\circ} \mathrm{W}$ and $3^{\circ} \mathrm{E}$ and from the Antarctic continental shelf to $60^{\circ} \mathrm{S}$. The combination of conductivity-temperature-depth (CTD) profile data and ship-mounted acoustic Doppler current profiler (ADCP) measurements was used to obtain a quasi-synoptic picture of the water mass distribution and circulation of the study area. The ADCP measurements provide measurements of the velocity field on scales normally not resolved by hydrographic stations and mooring locations and were used as an absolute reference for geostrophic current and transport estimates.

\section{Data and methods}

\subsection{Hydrographic survey and CTD profiler}

Between November 2005 and August 2006, two hydrographic cruises were conducted in the southeastern Weddell Sea aboard the R.V. Polarstern as part of the extensive field campaign of the Lazarev Sea Krill Study (LAKRIS), dedicated to identifying relationships between the physical environment and the abundance of zooplankton and especially krill. In total, 177 casts with a CTD type Sea-Bird Electronics SBE 911plus were made during both LAKRIS surveys, in order to map the hydrographic field of the study area (Table 1 ). Of these, 82 extended to full ocean depth, while the others were limited mostly to the upper $1000 \mathrm{~m}$ of the water column. All CTD stations were organized on a regular grid, made up of four meridional sections running between $60^{\circ} \mathrm{S}$ and $70^{\circ} \mathrm{S}$ and along $3^{\circ} \mathrm{E}, 0^{\circ} \mathrm{E}, 3^{\circ} \mathrm{W}$ and $6^{\circ} \mathrm{W}$ during the summer cruise (Fig. 1b). The entire transect along $6^{\circ} \mathrm{W}$ of the planned grid had to be abandoned due to difficult ice conditions during the following winter survey (Fig. 1c). The distance between stations along the meridional sections was nominally 30 nautical miles. Water samples were collected with a Sea-Bird Carousel sampler with 24 12-1 bottles. For in situ calibration, temperatures were measured with a digital thermometer Sea-Bird SBE35, and salinity samples were analyzed with a Guildline-Autosal-8400A salinometer onboard. The temperature sensor of the CTD was calibrated by the manufacturer a few months prior to the cruise and afterwards to accuracy better than $0.001 \mathrm{~K}$ for both surveys. Salinity derived from the CTD measurements was calibrated to a final accuracy of better than 0.002 for both cruises by comparison to the salinity samples.

\subsection{Vessel-mounted acoustic Doppler current profiler}

Vertical profiles of ocean currents down to $335 \mathrm{~m}$ depth were measured on board R.V. Polarstern continuously using a hull-mounted acoustic Doppler current profiler (Ocean Surveyor; Teledyne RD Instruments USA, Poway, California, $150 \mathrm{kHz}$ nominal frequency). The transducers were located $11 \mathrm{~m}$ below the water line and were protected against ice floes by an acoustically transparent plastic window. The velocity components $u$ (eastward), $v$ (northward) and $w$ (upward) were averaged in 2 min ensembles in $4 \mathrm{~m}$ thick depth bins between 19 and $335 \mathrm{~m}$ depth. The reference layer was set to bins $6-15$, avoiding near surface effects and biases near bin 1 . Heading, roll and pitch data from the ship's gyro platforms were used to convert the $\mathrm{ADCP}$ velocities into earth coordinates. The ship's velocity was calculated from position fixes obtained by the Global Positioning System (GPS) or DGPS if available. Accuracy of the ADCP velocities depends mainly on the quality of the position fixes and the ship's heading data. Further errors stem from a misalignment of the transducer with the ship's centerline. To reduce these errors, standard watertrack calibration methods (Joyce, 1989; Pollard and Read, 1989) were applied to provide a velocity scale factor and a constant angular offset between the transducer and the length axis of the ship. Further ADCP processing was carried out by using the CODAS3 software package developed by E. Firing and colleagues (Firing, 1991). Barotropic tidal currents were predicted and removed using the Circum-Antarctic Tide Model CATS02.01 developed by Padman et al. (2002). The magnitude of the predicted tides ranges between 0 and $2 \mathrm{~cm} \mathrm{~s}^{-1}$ along both $3^{\circ} \mathrm{E}$ transects. However, the two westernmost transects at $3^{\circ} \mathrm{W}$ and $6^{\circ} \mathrm{W}$ exhibit a maximum of about 5 and $12 \mathrm{~cm} \mathrm{~s}^{-1}$ on the Antarctic continental shelf, respectively.

\subsection{Deriving absolute velocities}

The average geostrophic current $v_{g}$ referenced to a velocity $v_{\text {ref }}$ on a certain isobaric surface between two CTD stations $A$ and $B$ was calculated as follows:

$v_{g}=\frac{1}{f L}\left(\Delta D_{B}-\Delta D_{A}\right)+v_{r e f}$

where $\left(\Delta D_{B}-\Delta D_{A}\right)$ is the difference in dynamic height, calculated from integrating over pressure the specific volume anomalies at stations, $B$ and $A$, separated by distance $L$, and $f$ is the Coriolis parameter. However, the difficulty inherent in the dynamic method, even if the density and the station locations are very well determined, is that the reference velocity is unknown and must be determined by other means. To overcome this problem, we used the referencing method presented by Pickart and Lindstrom (1994) and Cokelet et al. (1996) and combined the ADCP data with the baroclinic geostrophic currents derived from the hydrographic measurements. To obtain the ADCP-referenced geostrophic flow, the $u$ component of the ADCP currents after prior correction for tidal motion was spatially averaged between the CTD casts. This provided mean ADCP velocity profiles for the same horizontal spacing for which also the baroclinic geostrophic profiles were calculated. The baroclinic geostrophic velocities, which were always calculated relative to the deepest common level between neighboring station pairs, were adjusted to fit the normal ADCP velocity component for a specified depth range. For each pair of ADCP and baroclinic geostrophic profiles, that depth range was selected in which the shears matched best and so the averaged offset revealed a comparatively small standard deviation $\left(0.2-1.1 \mathrm{~cm} \mathrm{~s}^{-1}\right)$. The selected depth range varied from profile to profile between $81 \mathrm{~m}$ (minimum) and $301 \mathrm{~m}$ (maximum), to avoid effects both from surface forcing and weak signals close to the range limit. The difference between the two velocities over the reference depth interval ranges between $-7.5 \pm 0.2$ and $2.1 \pm 0.4 \mathrm{~cm} \mathrm{~s}^{-1}$ (summer survey) and between $-15.4 \pm 1.1$ and $2.5 \pm 0.5 \mathrm{~cm} \mathrm{~s}^{-1}$ (winter survey). The offset between the mean ADCP and the baroclinic geostrophic current component in the depth range of best-matching shears then constitutes the barotropic current component. The absolute current component is then obtained by adding the baroclinic and barotropic components. The spatial resolution of the derived absolute velocity field was $4 \mathrm{~m}$ in the vertical and $55 \mathrm{~km}$ horizontally, the latter being determined by the station spacing.

Table 1

Summary of cruise dates.

\begin{tabular}{|c|c|c|c|c|c|}
\hline Cruise & Objective & Start & End & No. CTD stations & Cruise report \\
\hline ANT-XXIII/2 & Summer 2005/2006 survey & $11 / 19 / 2005$ & $01 / 12 / 2006$ & 87 & Strass (2007) \\
\hline ANT-XXIII/6 & Winter 2006 survey & $06 / 17 / 2006$ & $08 / 21 / 2006$ & 90 & Bathmann (2008) \\
\hline
\end{tabular}


Averaging the ADCP data also helps to reduce the measurement uncertainty of single-ping ADCP measurements to acceptable levels. The manufacturer (Teledyne RDI) indicates a single-ping uncertainty of $\pm 30 \mathrm{~cm} \mathrm{~s}^{-1}$ for the $150 \mathrm{kHz}$ Ocean surveyor configured in long range mode with a bin length of $4 \mathrm{~m}$. The statistical uncertainty of the velocity measurements reduces to standard errors of $\pm 5 \mathrm{~cm} \mathrm{~s}^{-1}\left(30 /(\sqrt{37}) \mathrm{cm} \mathrm{s}^{-1}\right)$ if we average over 37 single pings, which corresponds to the theoretical precision of $u$ and $v$ averaged over $2 \mathrm{~min}$. In this study, about 100 individual ADCP ensembles made up a typical 55-km long section between a CTD pair. This implies an error in the section-averaged ADCP reference velocity of $\pm 0.5 \mathrm{~cm} \mathrm{~s}^{-1}\left(30 /(\sqrt{37} \times \sqrt{100}) \mathrm{cm} \mathrm{s}^{-1}\right)$.

\subsection{Error estimation for geostrophic referencing}

Errors in the calculation of the geostrophic velocity $d v_{g}$ result from uncertainties in the

$d v_{g}=\sqrt{\left(\frac{d \Delta D}{f L}\right)^{2}+\left(\frac{d L}{L} v_{g}\right)^{2}+\left(d v_{r e f}\right)^{2}}$

station spacing $d L$, uncertainties in the dynamic height anomaly $d \Delta D$, and uncertainties in the reference velocity $d v_{\text {ref }}$ (see Johns et al., 1989).

The estimated error in dynamic height, $d \Delta D$, can be calculated from the estimated error in the specific volume anomaly $d \delta$, which depends on the measurement errors in temperature, salinity and pressure $\left(\Delta T=0.001 \mathrm{~K}, \Delta S=0.002, \Delta p=1 \times 10^{4} \mathrm{~Pa}\right)$.

$d \delta=\left(\frac{\partial \delta}{\partial T}\right) d T+\left(\frac{\partial \delta}{\partial S}\right) d S+\left(\frac{\partial \delta}{\partial p}\right) d p$

The partial derivative of $\delta$ with respect to pressure is neglected because it does not contribute to the horizontal gradients in $d \Delta D$ along isobaric surfaces. The partial derivatives were estimated using variations of a typical mean $T-S$ profile within the Lazarev Sea

$\frac{\partial \delta}{\partial T}=5.6 \times 10^{-7} \mathrm{~m}^{3} \mathrm{~kg}^{-1} \mathrm{~K}^{-1}$

$\frac{\partial \delta}{\partial S}=2.9 \times 10^{-7} \mathrm{~m}^{3} \mathrm{~kg}^{-1}$

$d \delta=\sqrt{\left(\frac{\partial \delta}{\partial T} d T\right)^{2}+\left(\frac{\partial \delta}{\partial S} d S\right)^{2}}=8.1 \times 10^{-10} \mathrm{~m}^{3} \mathrm{~kg}^{-1}$

These variations lead to an ultimate error of approximately $0.045 \mathrm{~m}^{2} \mathrm{~s}^{-2}$ between the surface and the 5500-dbar isobar.

$d \Delta D=d \delta d p=0.045 \mathrm{~m}^{2} \mathrm{~s}^{-2}$

Thus, the dynamic height component of the velocity error is $d v_{g}=$ $d \Delta D / f L=0.045 \mathrm{~m}^{2} \mathrm{~s}^{-2} /\left(1.3 \times 10^{-4} \mathrm{~s}^{-1} \times 55560 \mathrm{~m}\right)=0.6 \mathrm{~cm} \mathrm{~s}^{-1}$.

The second error in geostrophic velocity arises from the uncertainties in station spacing. The maximum position uncertainty for each CTD station was $\pm 50 \mathrm{~m}$, leading to an error of

$d L=\sqrt{50^{2}+50^{2}}= \pm 71 \mathrm{~m}$

The velocity error due to inaccuracy in determining the station spacing is $d v_{g}=d L / L \times v_{g}=(71 \mathrm{~m} / 55560 \mathrm{~m}) \times 0.1 \mathrm{~m} \mathrm{~s}^{-1}=$ $0.01 \mathrm{~cm} \mathrm{~s}^{-1}$.

The third error in geostrophic velocity arises from the uncertainties in the reference velocity $d v_{\text {ref }}$. Errors in the ADCP reference velocity derive mainly from two sources, namely instrument error and ageostrophic motion, including Ekman drift currents, tides, internal waves or inertial oscillations. For this reason tides were removed from the ADCP velocities using the CATS02.01 Tide Model (Padman et al., 2002). To analyze whether the wind field has an effect on the referenced velocity or not we estimated the Ekman depth $D_{E}$ after Pond and Pickard (1983), where $W$ is the wind speed, which was measured aboard R.V. Polarstern, and $\phi$ is the geographical latitude.

$D_{E}=\frac{4.3 W}{\sqrt{(\sin |\phi|)}}$

The Ekman depth varied between 19.8 and $80.2 \mathrm{~m}$ during the summer survey and between 14.2 and $69.3 \mathrm{~m}$ during the winter survey, well above the chosen reference layer to avoid effects from wind forcing. Thus the influence of the Ekman drift on the currents at the reference depth can be neglected. The predicted barotropic tide is less than $2 \mathrm{~cm} \mathrm{~s}^{-1}$, except on the Antarctic continental shelf, where it exceeds $10 \mathrm{~cm} \mathrm{~s}^{-1}$ at $6^{\circ} \mathrm{W}$. Other contributions to the flow field such as ageostrophic mesoscale motions, we assume to account for an error of the order of $2 \mathrm{~cm} \mathrm{~s}^{-1}$. Adding their variances to the instrument error estimated as $0.5 \mathrm{~cm} \mathrm{~s}^{-1}$, the square root of the sum yields a net reference layer standard deviation of about $2 \mathrm{~cm} \mathrm{~s}^{-1}$. Following Eq. (2) this leads to a mean accuracy of the absolute geostrophic velocity

$d v_{g}=\sqrt{\left(0.6 \mathrm{cms}^{-1}\right)^{2}+\left(0.01 \mathrm{cms}^{-1}\right)^{2}+\left(2 \mathrm{cms}^{-1}\right)^{2}}=2 \mathrm{cms}^{-1}$

\section{Results}

\subsection{Hydrographic structure}

The waters of the Lazarev Sea observed in this study are classified into four major water masses according to their potential temperature $(\theta)$ and salinity $(S)$ characteristics (Fig. 2). In our nomenclature we mostly follow the definitions of Carmack and Foster (1975). Hydrographic conditions in the study area during austral summer 2005/2006 and austral winter 2006 are illustrated by two meridional sections along $3^{\circ} \mathrm{E}$ from $60^{\circ} \mathrm{S}$ to $70^{\circ} \mathrm{S}$ (Figs. 3 and 4 ).

\section{a}

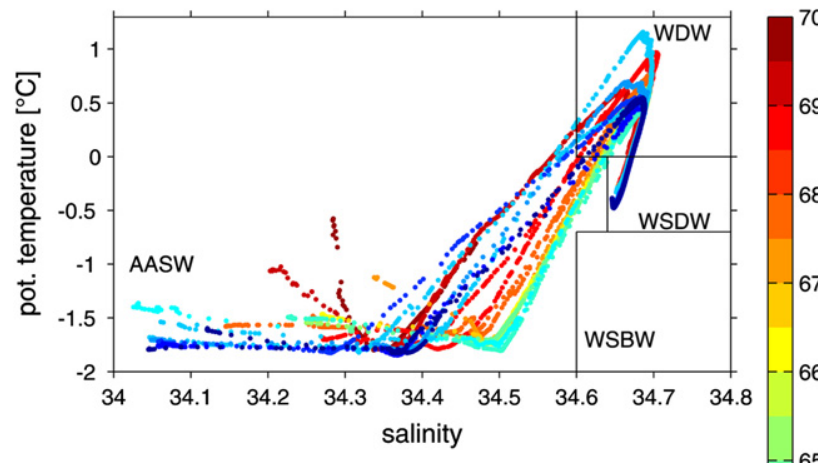

b

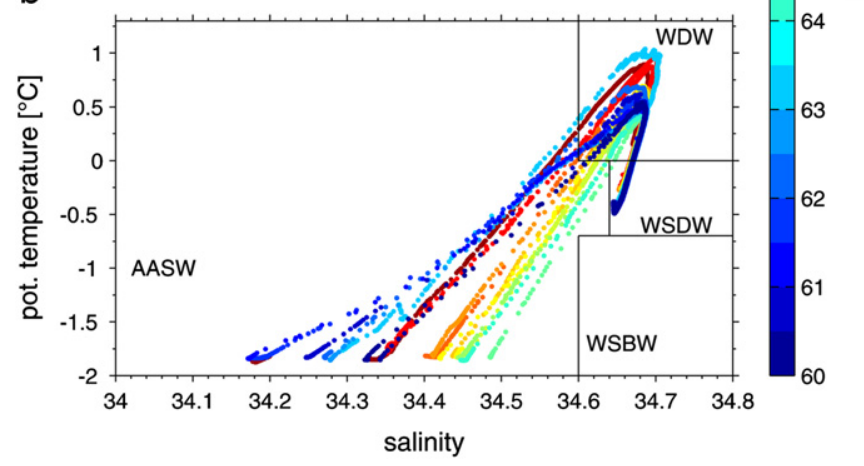

Fig. 2. Potential temperature versus salinity diagram for the $3^{\circ} \mathrm{E}$ transect from austral summer 2005/2006 (a) and austral winter 2006 (b). AASW=Antarctic Surface Water, WDW $=$ Warm Deep Water, WSDW $=$ Weddell Sea Deep Water and WSBW $=$ Weddell Sea Bottom Water. 
a

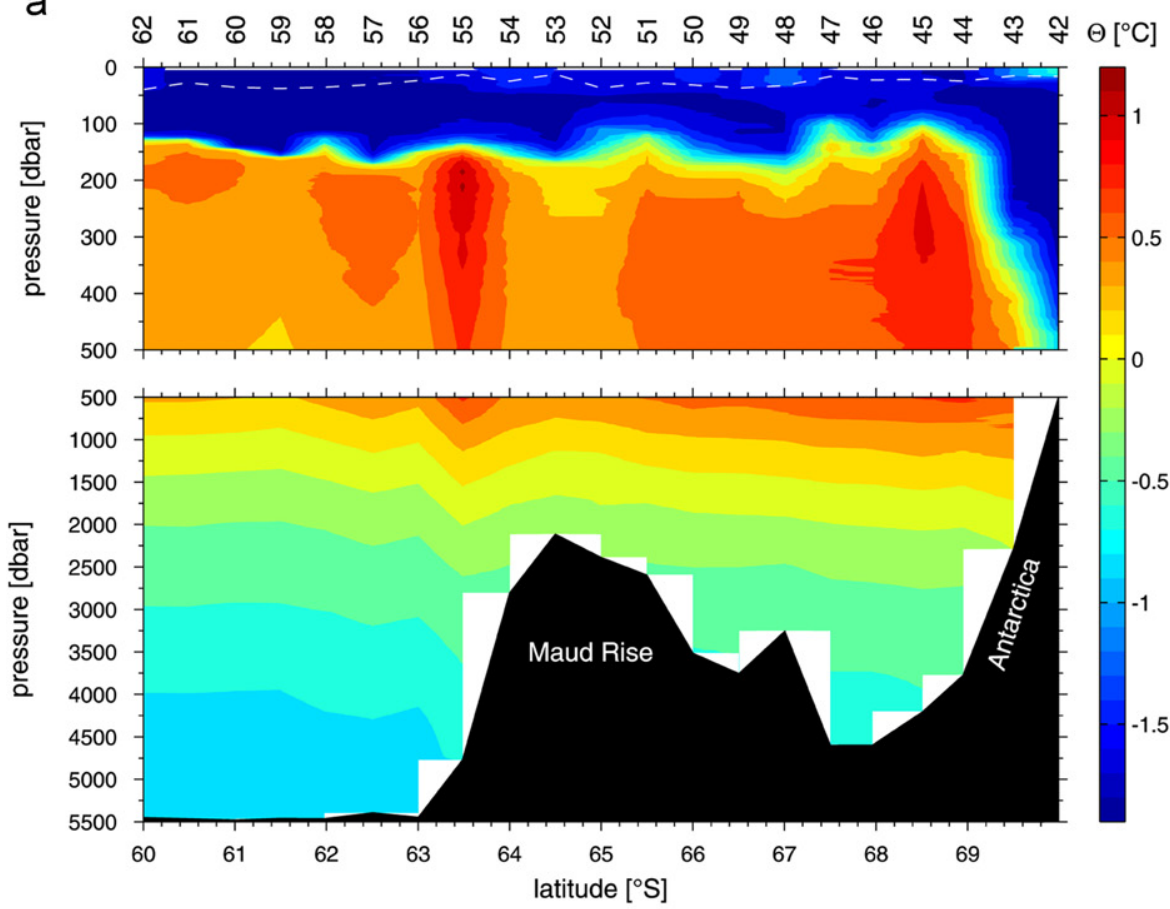

b
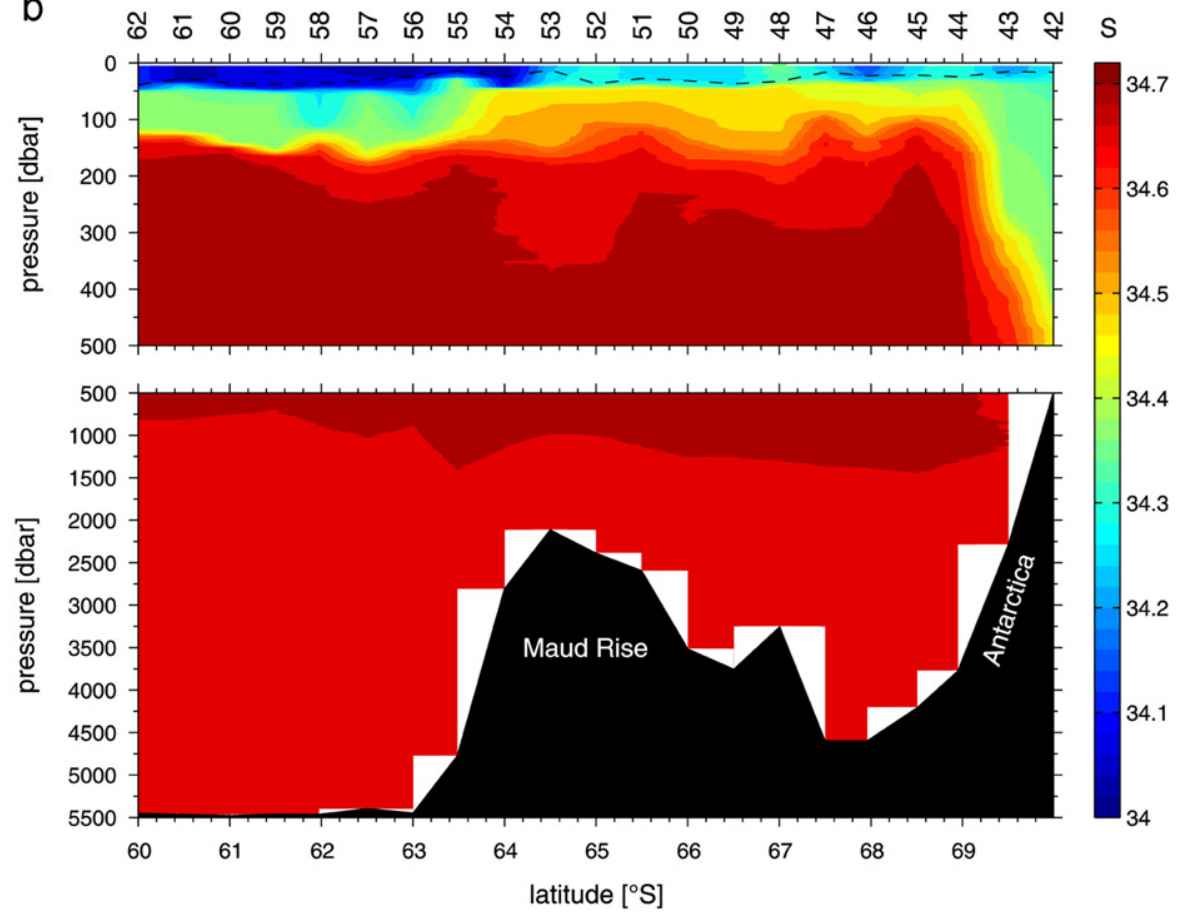

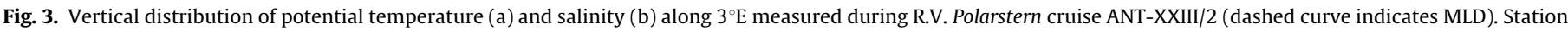
numbers are marked at the top of the section.

The open ocean surface layer consists mainly of less saline and (near)-freezing-point Antarctic Surface Water (AASW). During the austral summer, after the sea ice recedes, the Winter Water (WW) is overlain by a shallow layer of low-salinity and slightly warmed meltwater. The mean mixed layer depth (MLD) was estimated at $25 \pm 9 \mathrm{~m}$ using the mixed layer criterion introduced by Cisewski et al. $(2005,2008)$. Underneath the AASW the Warm Deep Water (WDW) is found, which is the warmest water mass observed in the study area and is defined by potential temperatures $\theta>0{ }^{\circ} \mathrm{C}$. The maximum temperature of the WDW is accompanied by a salinity maximum of about 34.7. Whereas the northern slope of Maud Rise is overlain by a pronounced warm WDW core $\left(\theta_{\operatorname{Max}}=1.16^{\circ} \mathrm{C}\right)$, the maximum temperature is much lower near the top of Maud Rise $\left(\theta_{\text {Max }}=0.42{ }^{\circ} \mathrm{C}\right)$. Between the southern flank of the seamount and $68^{\circ} \mathrm{S} \theta_{\text {Max }}$ gradually increases from 0.6 to $0.76{ }^{\circ} \mathrm{C}$. A second isolated core of warm WDW with a temperature maximum of $0.97^{\circ} \mathrm{C}$ is found near the continental slope at $68.5^{\circ} \mathrm{S}$. At $69^{\circ} \mathrm{S}$ the surface layer deepens from $120 \mathrm{~m}$ towards the shelf break to more than 600 m near the Antarctic Slope Front(ASF), which separates the Winter Water and the Warm Deep Water from the colder and less saline Shelf Waters near the Antarctic continent. The cold water mass underneath the WDW with potential temperatures between 0 and $-0.7{ }^{\circ} \mathrm{C}$ is the Weddell Sea Deep Water (WSDW). Only 
a
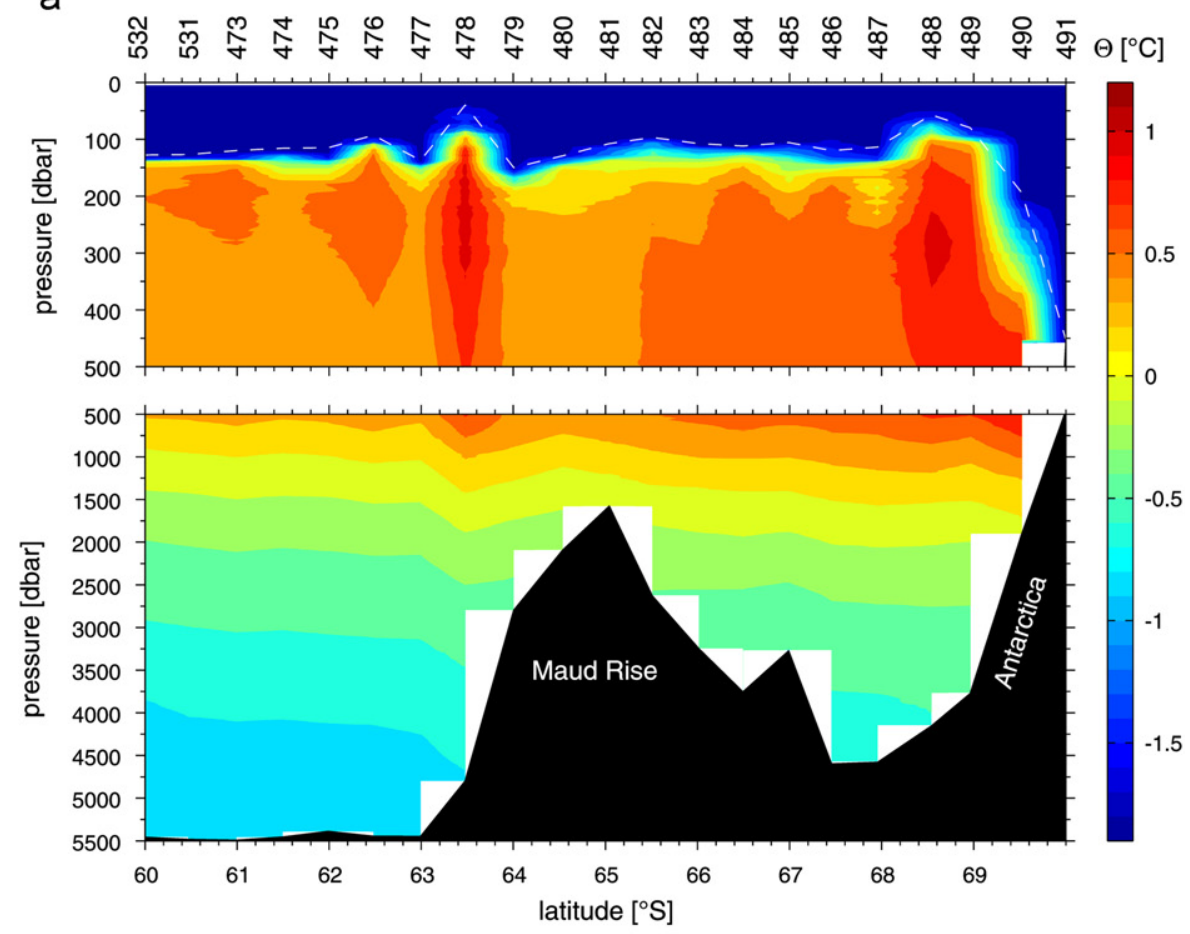

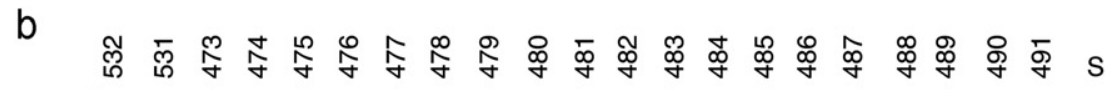

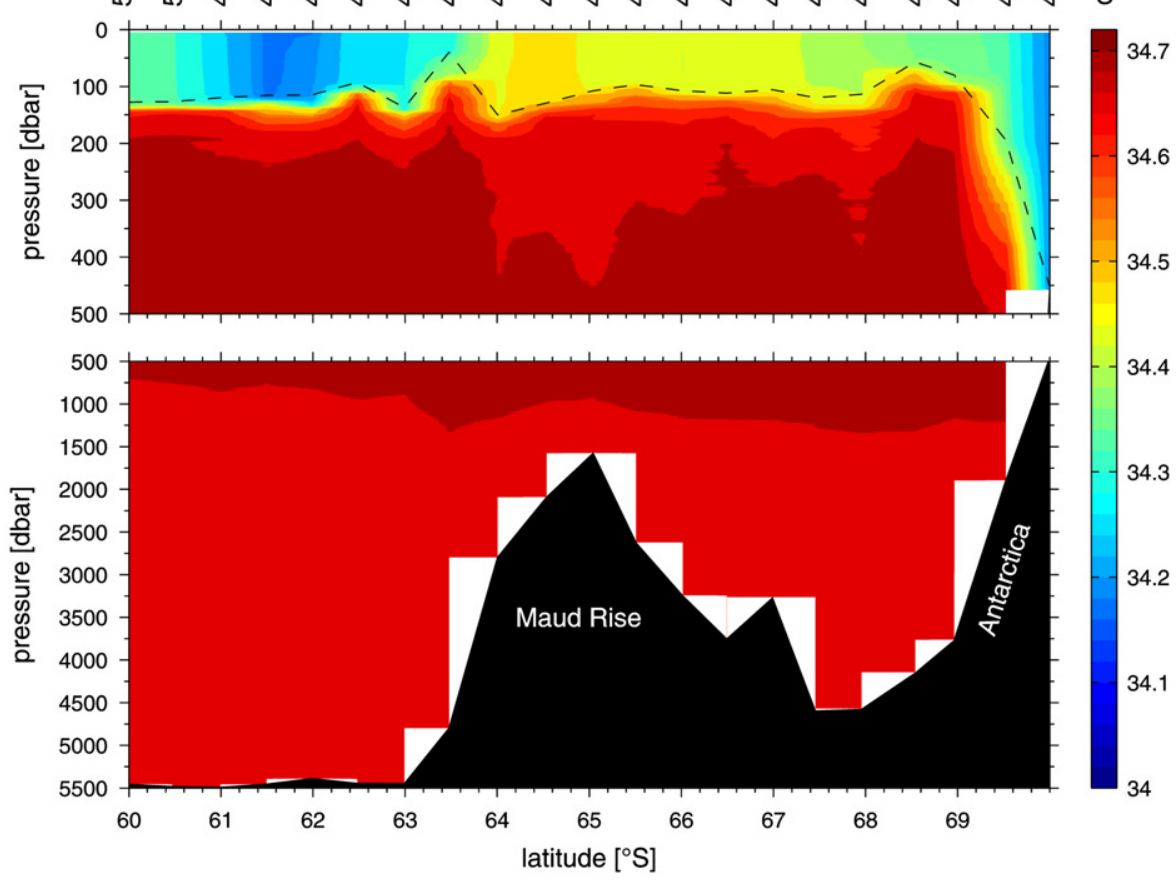

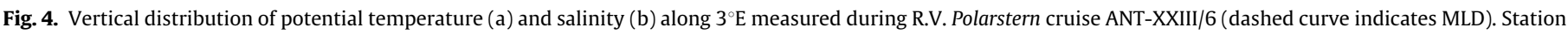
numbers are marked at the top of the section.

north of Maud Rise is Weddell Sea Bottom Water (WSBW) with potential temperature below $-0.7^{\circ} \mathrm{C}$ found at the sea floor.

During the austral winter, the mixed layer forms a nearly homogeneous layer of Winter Water (WW), which represents the (near)freezing-point type of AASW with an average thickness of $108 \pm 26 \mathrm{~m}$ between $60^{\circ}$ and $69^{\circ} \mathrm{S}$ (Fig. 4). Further south, the MLD deepens from 80 to $453 \mathrm{~m}$ between the ASF and the continental shelf. However, it is remarkable that the WDW layer reveals almost similar patterns as observed during the foregoing summer (Fig. 3). The northern slope of Maud Rise is overlain by a warm WDW core $\left(\theta_{\operatorname{Max}}=1.16{ }^{\circ} \mathrm{C}\right)$. At this station the WDW is lifted up into the upper $100 \mathrm{~m}$. A second isolated core of warm WDW with a maximum potential temperature of $0.97{ }^{\circ} \mathrm{C}$ is found near the continental slope at $68.5^{\circ} \mathrm{S}$.

\subsection{Circulation and transport}

\subsubsection{Direct measurements}

Fig. 5a illustrates the horizontal currents from the depth range 150-200 m along the track for the summer survey, measured with 

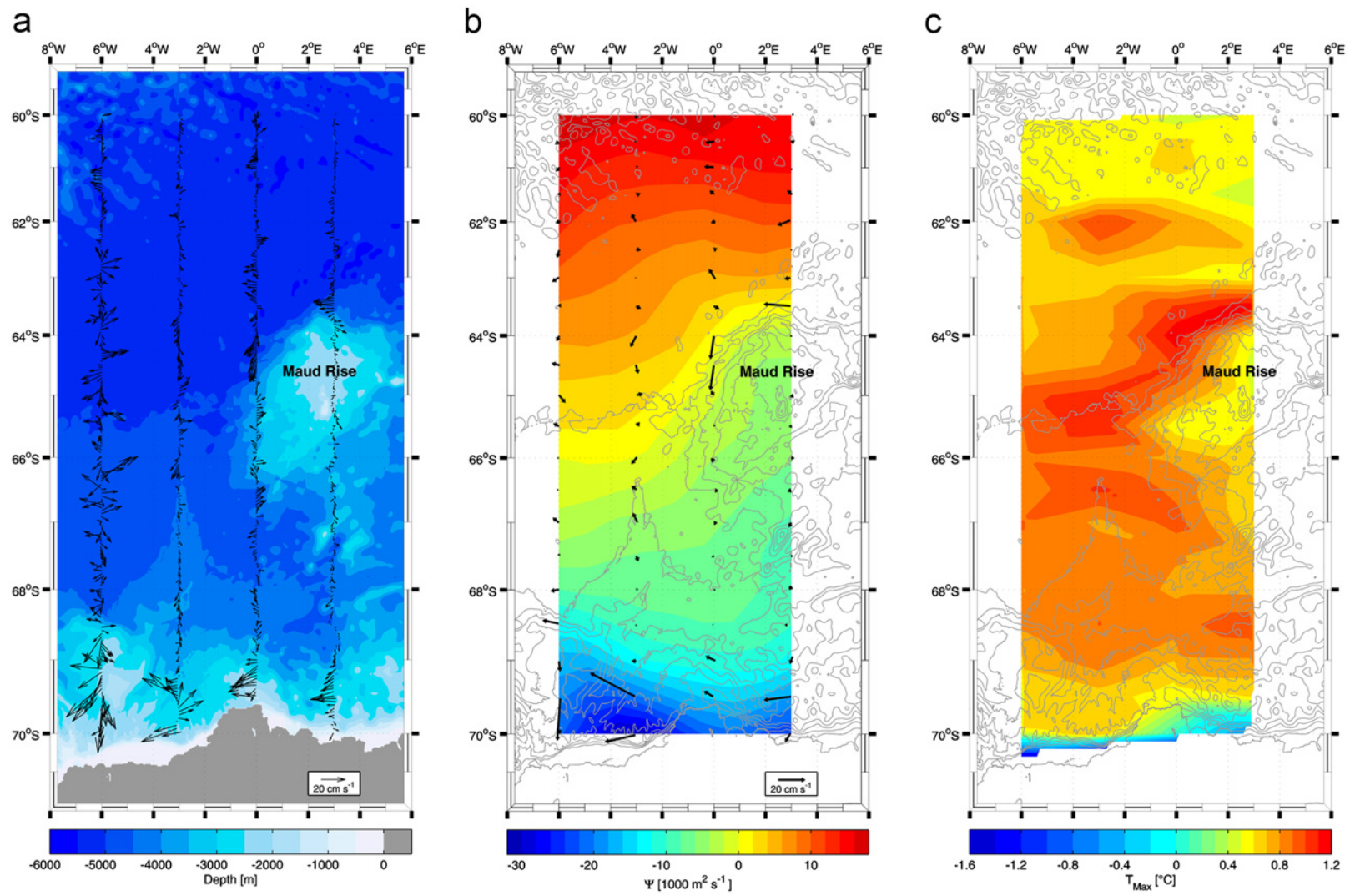

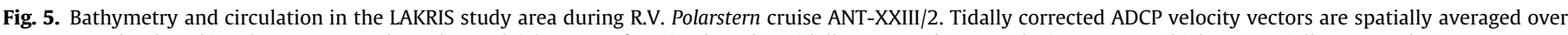

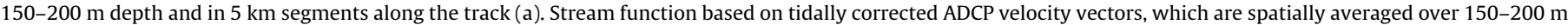
depth and temporarily averaged for periods of hydrographic station work (b). Horizontal distribution of the temperature maximum (c).
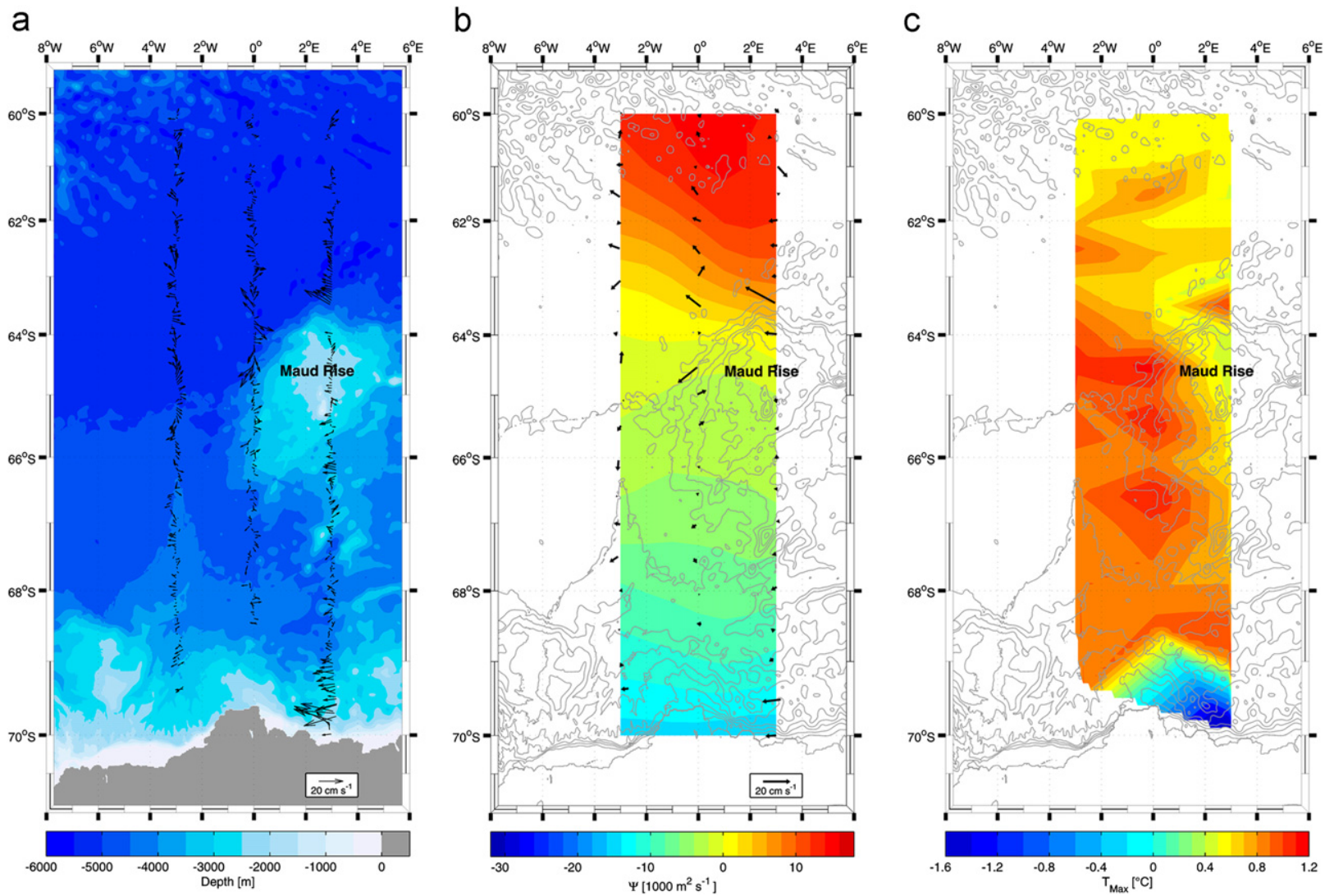

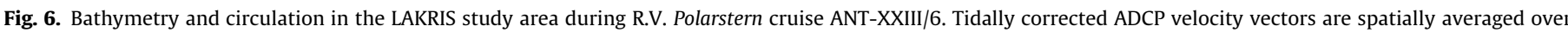

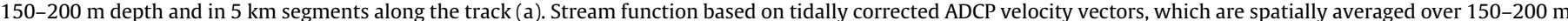
depth and temporarily averaged for periods of hydrographic station work (b). Horizontal distribution of the temperature maximum (c). 
the ADCP and averaged in $5 \mathrm{~km}$ segments after the correction for tides. The vectors show the highest velocities within the westward flowing Antarctic Coastal Current (AntCC), which is confined to the Antarctic continental shelf slope and is associated with maximum velocities of about $21-42 \mathrm{~cm} \mathrm{~s}^{-1}$, and a westward then southwestward circulation around the northern and northwestern flanks of Maud Rise with maximum velocities of about $20-23 \mathrm{~cm} \mathrm{~s}^{-1}$, respectively. This jet is $30-50 \mathrm{~km}$ wide and follows the 4000 and $5000 \mathrm{~m}$ isobaths, which locally correspond to the deepest part of the slope of the seamount. However, just south of this jet, recirculation occurs in a narrow band with maximum velocities of about $\sim 15 \mathrm{~cm} \mathrm{~s}^{-1}$. Near the top of Maud Rise the velocities are small. At the two westernmost transects the velocity field is dominated by a number of mesoscale features indicating of eddies and meanders.

Fig. 5b shows the stream function based on the tidally corrected ADCP data, which are vertically averaged between 150 and $200 \mathrm{~m}$ and temporarily averaged for the periods of hydrographic station work. The stream function was obtained by first simultaneously objectively analyzing the velocity components onto a regular grid taking the correlations between the components into account, then calculating the vorticity and finally solving a Poisson equation to obtain the stream function. The two most striking features are two strong jets, one between $63^{\circ}$ and $64^{\circ} \mathrm{S}$, over the northern flank of Maud Rise, and another between $69^{\circ}$ and $70^{\circ} \mathrm{S}$, close to the continental shelf slope. The stream function reveals a westward and southwestward circulation around the northwestern edge of Maud Rise and the AntCC following the Antarctic continental shelf; the maximum velocities calculated from the stream function are 8 and $20 \mathrm{~cm} \mathrm{~s}^{-1}$, respectively. The horizontal distribution of the $T_{M a x}$ temperature agrees well with this circulation pattern (Fig. 5c) and suggests that WDW enters thorough the Lazarev Sea via the Maud Rise Jet and the offshore part of the AntCC. The warmest WDW passes along the northern flank of Maud Rise and forms a pool immediately to the west, as far as $6^{\circ} \mathrm{W}$. A second, isolated, pool is apparent at $62^{\circ} \mathrm{S}, 3^{\circ} \mathrm{W}$. The second gateway for WDW is the westward flowing AntCC between $69^{\circ} \mathrm{S}$ and $70^{\circ} \mathrm{S}$.

Fig. 6a illustrates the tidally corrected horizontal currents in the depth range 150-200 m measured with the ADCP and averaged in $5 \mathrm{~km}$ segments along the track for the winter survey. The entire transect along $6^{\circ} \mathrm{W}$ and the southernmost stations along the $0^{\circ} \mathrm{E}$ and $3^{\circ} \mathrm{E}$ transects had to be abandoned due to severe ice conditions. Unfortunately, there is also a gap in the ADCP data due to a failure in the ship's navigational system along the $3^{\circ} \mathrm{E}$ transect between $63.5^{\circ} \mathrm{S}$ and $64^{\circ} \mathrm{S}$, which coincides with a major part of the northern gateway for WDW. The vectors along the $3^{\circ} \mathrm{E}$ transect reveal the highest velocities within the AntCC of about $34 \mathrm{~cm} \mathrm{~s}^{-1}$. The stream function also reveals the two strong jets over the northern flank of Maud Rise and close to the continental shelf slope (Fig. 6b). However, the northern jet splits off into two branches at about $64^{\circ} \mathrm{S}, 0^{\circ} \mathrm{E}$. While the northern branch flows in northwestward direction, the southern branch flows southwestward. Interestingly, Fig. $6 \mathrm{c}$ shows a discontinuity of the $T_{\text {Max }}$-distribution around the northwestern edge of Maud Rise.

\subsubsection{Baroclinic current and transport}

The baroclinic velocities perpendicular to the $3^{\circ} \mathrm{E}$ section (Fig. 7), calculated relative to the deepest common levels of neighboring station pairs by the geostrophic method, reveal highest velocities within the westward flowing AntCC with maximum baroclinic velocities of about $6 \mathrm{~cm} \mathrm{~s}^{-1}$ (summer) and $10 \mathrm{~cm} \mathrm{~s}^{-1}$ (winter), and a westward flowing jet over the northern slope of Maud Rise with maximum velocities of about $10 \mathrm{~cm} \mathrm{~s}^{-1}$ (summer) and $7 \mathrm{~cm}$ $\mathrm{s}^{-1}$ (winter). Recirculation occurs in a small stream band just south of the Maud Rise Jet. Elsewhere, the baroclinic velocities are rather weak. The net baroclinic transport across the $3^{\circ} \mathrm{E}$ section amounts to
20.1 and $16.9 \mathrm{~Sv}$ westward for the summer and winter season, respectively (Table 2 ). In both seasons at least $\sim 60 \%$ of the net baroclinic transport occurs within the northern part of the section between $60^{\circ}$ and $65^{\circ} \mathrm{S}$ (Table 3). The major contributions to the total baroclinic transport stem from the Maud Rise Jet, which is located between $63^{\circ} \mathrm{S}$ and $63.5^{\circ} \mathrm{S}$ and accounts for 13.0 and $7.9 \mathrm{~Sv}$, and from the AntCC between $69^{\circ} \mathrm{S}$ and $70^{\circ} \mathrm{S}$, which accounts for 2.3 and $3.1 \mathrm{~Sv}$ during the summer (Fig. 9, Table 2) and the winter survey (Fig. 10, Table 2 ), respectively.

\subsubsection{ADCP-referenced geostrophic current and transport}

Prior to adjustment, the baroclinic currents were referenced to the deepest common levels of neighboring station pairs where $u=0$ is assumed. The magnitude of the adjustments from relative to absolute velocities along the $3^{\circ} \mathrm{E}$ transect range from -7.5 to $2.1 \mathrm{~cm} \mathrm{~s}^{-1}$ for the summer survey. Thus, the ADCP-referenced geostrophic current is usually stronger than the bottom-referenced current. Due to the high barotropic currents, the ADCP-referenced geostrophic flow field essentially appears columnar and does not show a level of no motion (Fig. 8a) in major parts of the section. The current field reveals several branches with alternating eastward and westward components. Strong westward flow of about $10 \mathrm{~cm} \mathrm{~s}^{-1}$ occurs in a $110 \mathrm{~km}$ wide jet above the northern slope of Maud Rise between $63^{\circ}$ and $64^{\circ} \mathrm{S}$ and above the Antarctic continental shelf between $69^{\circ}$ and $70^{\circ} \mathrm{S}$. Relatively weak eastward flows of about $1-3 \mathrm{~cm} \mathrm{~s}^{-1}$ occur between $60^{\circ} \mathrm{S}$ and $61.5^{\circ} \mathrm{S}$, likely related to the northern, eastward-flowing limb of the Weddell Gyre, and between $64^{\circ}$ and $68^{\circ} \mathrm{S}$, above the top of Maud Rise and its southern more gradual topographic slope. The meridional distribution of the ADCP-referenced geostrophic volume transports across the $3^{\circ} \mathrm{E}$ section is shown in Fig. 9 and in Table 2 with corresponding estimates of the accuracy. The Maud Rise Jet (63-64 $\left.{ }^{\circ} \mathrm{S}\right)$ and the AntCC (69-70'S) provide the major contributions to the net transport of about $23.9 \pm$ 19.9 Sv westward (Fig. 9, Table 2).

Six months later, the ADCP-referenced geostrophic flow field also reveals a predominantly barotropic structure without any clear level of no motion (Fig. 8b). However, strong westward velocities cover a wider portion of the transect than in summer and result into a total transport of $93.6 \pm 20.1 \mathrm{~Sv}$ (Fig. 10, Table 2). The magnitude of the adjustments from relative to absolute velocities along the $3^{\circ} \mathrm{E}$ transects range from -15.4 to $2.5 \mathrm{~cm} \mathrm{~s}^{-1}$. The highest velocities of about 10 and $25 \mathrm{~cm} \mathrm{~s}^{-1}$ are found within the Maud Rise Jet and the AntCC.

Calculation of water mass transports from these data is straightforward, but we need to stress the sensitivity of this integration to even relatively small ADCP errors. Since the WSDW and the WSBW encompass the deepest layers of the cross section at depths where the baroclinic geostrophic velocity profile is almost zero, the error in the ADCP reference velocity gains more importance here than in the upper layers. Therefore, we lay our focus on the WDW, which encompasses the upper 100 to $\sim 1000 \mathrm{~m}$, where errors in the ADCP reference velocity are of less influence than at greater depth. By multiplying the areas occupied by the WDW $\left(\mathrm{S}>34.6, \theta>0.0^{\circ} \mathrm{C}\right)$ and the perpendicular derived absolute current field, the WDW transport was obtained. During austral summer the net absolute transport of WDW accounts for $11.3 \mathrm{~Sv}$ which corresponds to one half of the total transport. It represents the balance of westward inflow and eastward recirculation, which itself accounts for $-9.1 \mathrm{~Sv}$. Interestingly, $\sim 98 \%$ of the WDW enters the Lazarev Sea via the northern part. Six months later the net absolute transport of WDW has increased by a factor of three and accounts for $30.7 \mathrm{~Sv}$ which corresponds to one third of the total transport of about 93.6 Sv. The fraction of recirculating WDW contributes $-3.3 \mathrm{~Sv}$ to the total transport. The WDW transport in this case is partitioned into $19.1 \mathrm{~Sv}(62 \%)$ north of $65^{\circ} \mathrm{S}$ and into $11.6 \mathrm{~Sv}$ (38\%) south of $65^{\circ} \mathrm{S}$ (Table 3). 
a

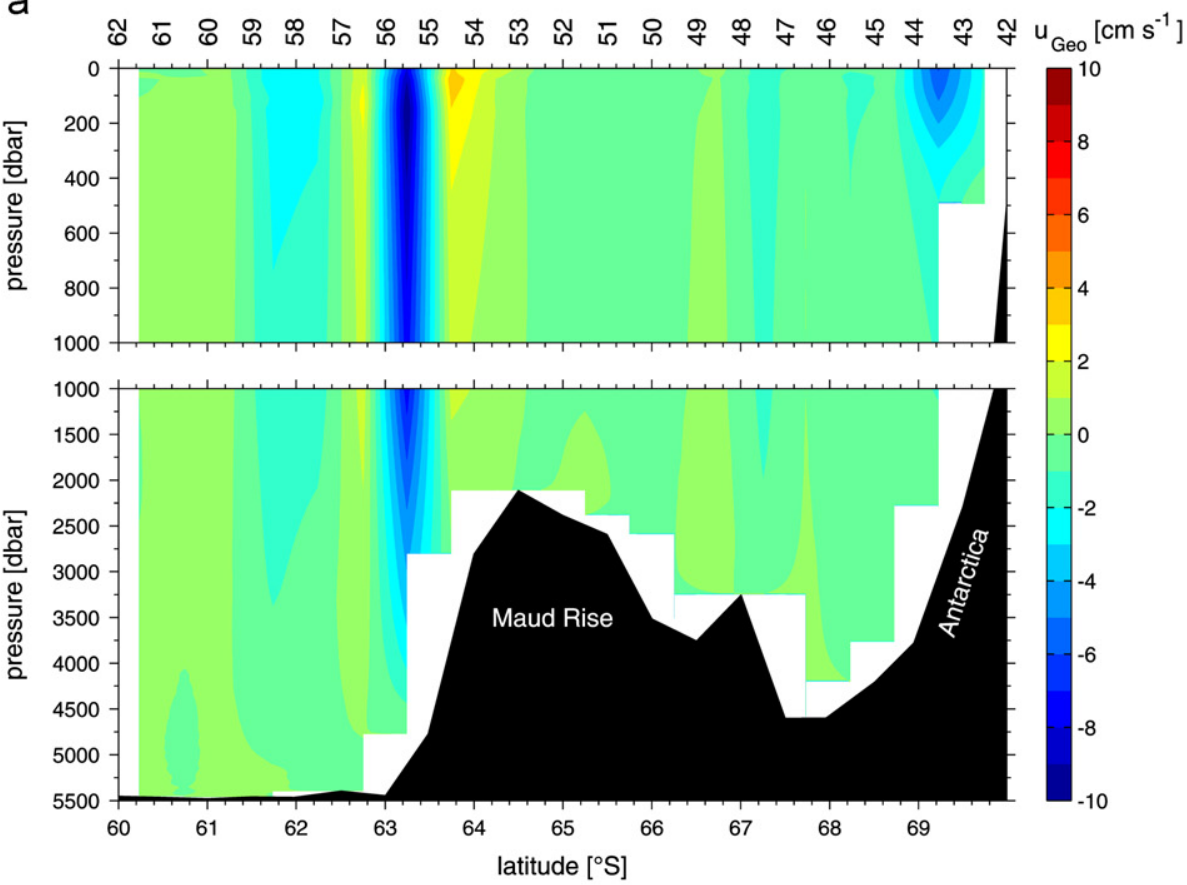

b
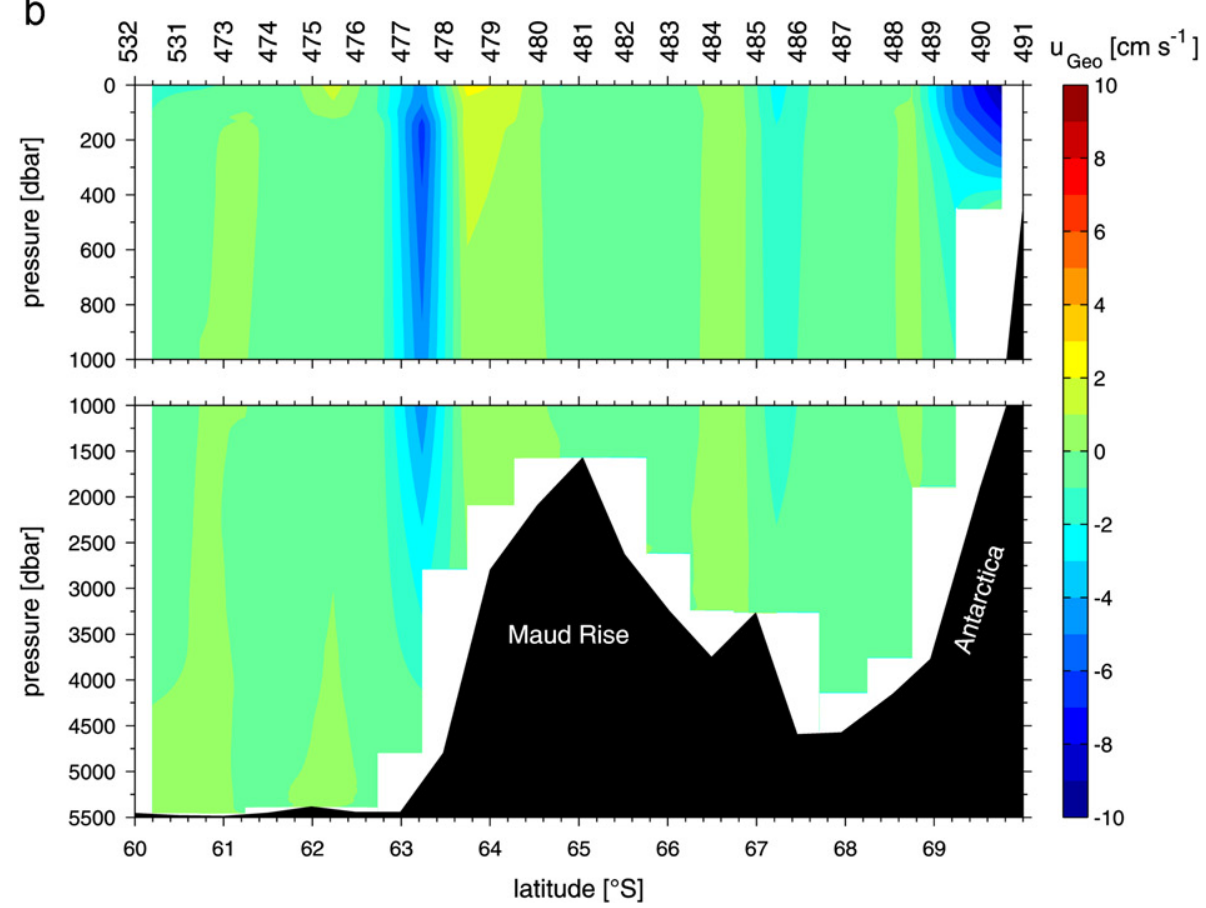

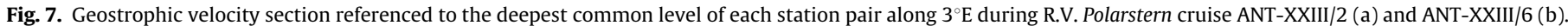
Isotachs are in $\mathrm{cm} \mathrm{s}^{-1}$, and positive normal velocities represent eastward flow.

\section{Discussion}

Two hydrographic surveys performed during austral summer 2005/2006 and austral winter 2006, which cover the southern limb of the Weddell Gyre in the Lazarev Sea, were used to derive an approximately synoptic picture of the hydrographic structure, circulation, and transport within the study area. The distribution of water masses along each of the meridional transects suggests that two gateways exist through which warm deep water masses enter through the Lazarev Sea. WDW enters the study area at $63.5^{\circ} \mathrm{S}$ and flows within a topographically trapped westward and southwestward jet around the northwestern edge of Maud Rise with maximum velocities of about $21-23 \mathrm{~cm} \mathrm{~s}^{-1}$, which corroborate the results of de Steur et al. (2007) who observed strong subsurface velocities up to $20 \mathrm{~cm} \mathrm{~s}^{-1}$ above the northern flank of the Rise during the 2005 MaudNESS winter field campaign. WDW cores $\left(T_{\text {Max }}=1^{\circ} \mathrm{C}\right)$ travel along the northern and western slope and contribute to a huge warm pool west of Maud Rise. Our results are in general agreement with previously reported hydrographic studies, e.g. those of Gordon and Huber (1995) and Bersch et al. (1992), who discussed the bathymetric effects of the Maud Rise on the stratification and circulation of the Weddell Gyre and showed 
Table 2

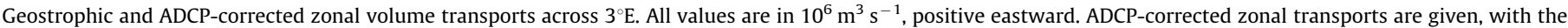
standard error.

\begin{tabular}{|c|c|c|c|c|c|}
\hline \multicolumn{3}{|c|}{ Austral summer 2005/2006 } & \multicolumn{3}{|c|}{ Austral winter 2006} \\
\hline Latitude & $M_{\mathrm{Geo}}$ & $M_{\mathrm{Abs}}$ & Latitude & $M_{\mathrm{Geo}}$ & $\mathrm{M}_{\mathrm{Abs}}$ \\
\hline-60.2323 & 0.0 & $2.4 \pm 6.0$ & -60.1938 & -1.8 & $6.4 \pm 6.8$ \\
\hline-60.7424 & 0.5 & $1.4 \pm 6.4$ & -60.7315 & 0.2 & $4.5 \pm 6.6$ \\
\hline-61.2504 & 0.4 & $1.9 \pm 6.0$ & -61.2434 & -0.1 & $-9.0 \pm 6.1$ \\
\hline-61.7359 & -3.3 & $-5.4 \pm 5.8$ & -61.7413 & -0.6 & $-18.7 \pm 5.9$ \\
\hline-62.2402 & -2.7 & $-6.2 \pm 6.4$ & -62.2338 & -0.1 & $-15.8 \pm 5.9$ \\
\hline-62.7542 & 2.5 & $1.9 \pm 6.0$ & -62.7353 & -1.0 & $-13.1 \pm 6.2$ \\
\hline-63.2436 & -13.0 & $-14.0 \pm 5.1$ & -63.2338 & -7.9 & $-17.5 \pm 5.2$ \\
\hline-63.7421 & 1.8 & $-10.3 \pm 3.2$ & -63.7400 & 1.0 & $-5.2 \pm 3.3$ \\
\hline-64.2492 & 0.6 & $1.9 \pm 2.3$ & -64.2695 & 0.5 & $-0.3 \pm 2.5$ \\
\hline-64.7475 & -0.3 & $0.5 \pm 2.3$ & -64.7884 & -0.3 & $-0.5 \pm 1.8$ \\
\hline-65.2475 & -0.1 & $2.7 \pm 2.7$ & -65.2750 & -0.4 & $-0.4 \pm 1.6$ \\
\hline-65.7504 & -0.5 & $1.3 \pm 2.9$ & -65.7613 & -0.4 & $0.6 \pm 3.0$ \\
\hline-66.2528 & -0.2 & $2.8 \pm 3.9$ & -66.2537 & -0.2 & $-4.7 \pm 3.5$ \\
\hline-66.7530 & 0.5 & $1.4 \pm 3.6$ & -66.7408 & 1.0 & $1.2 \pm 3.6$ \\
\hline-67.2519 & -1.9 & $1.4 \pm 3.6$ & -67.2219 & -2.2 & $2.1 \pm 3.4$ \\
\hline-67.7303 & 0.2 & $3.4 \pm 4.7$ & -67.7040 & -0.4 & $0.1 \pm 5.1$ \\
\hline-68.2321 & -1.6 & $-3.1 \pm 5.1$ & -68.2458 & -1.2 & $-6.4 \pm 5.4$ \\
\hline-68.7267 & -0.7 & $-0.1 \pm 3.8$ & -68.7503 & 0.1 & $-3.4 \pm 3.5$ \\
\hline-69.2234 & -2.0 & $-6.4 \pm 2.8$ & -69.2412 & -1.8 & $-8.4 \pm 2.4$ \\
\hline-69.7441 & -0.3 & $-1.4 \pm 0.5$ & -69.7594 & -1.3 & $-5.1 \pm 0.5$ \\
\hline Total & -20.1 & $-23.9 \pm 19.9$ & Total & -16.9 & $-93.6 \pm 20.1$ \\
\hline
\end{tabular}

Table 3

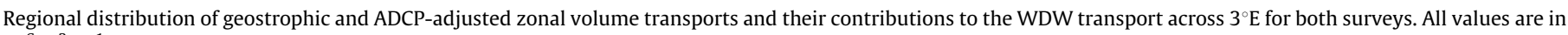
$10^{6} \mathrm{~m}^{3} \mathrm{~s}^{-1}$, positive eastward.

\begin{tabular}{|c|c|c|c|c|c|c|c|c|c|}
\hline \multicolumn{5}{|c|}{ Austral summer 2005/2006 } & \multicolumn{5}{|c|}{ Austral winter 2006} \\
\hline Latitude & $M_{\mathrm{Geo}}$ & $M_{\mathrm{WDW}}$ & $M_{\mathrm{Abs}}$ & $M_{\mathrm{WDW}}$ & Latitude & $M_{\mathrm{Geo}}$ & $M_{\mathrm{WDW}}$ & $M_{\mathrm{Abs}}$ & $M_{\mathrm{WDW}}$ \\
\hline $60^{\circ} \mathrm{S}-65^{\circ} \mathrm{S}$ & -13.5 & -5.3 & -25.9 & -11.1 & $60^{\circ} \mathrm{S}-65^{\circ} \mathrm{S}$ & -10.1 & -3.9 & -69.2 & -19.1 \\
\hline $65^{\circ} \mathrm{S}-70^{\circ} \mathrm{S}$ & -6.6 & -3.8 & 2.0 & -0.2 & $65^{\circ} \mathrm{S}-70^{\circ} \mathrm{S}$ & -6.8 & -3.4 & -24.4 & -11.6 \\
\hline Total & -20.1 & -9.1 & -23.9 & -11.3 & Total & -16.9 & -7.3 & -93.6 & -30.7 \\
\hline
\end{tabular}

a quasi-stationary pool of relatively warm WDW immediately west of this seamount, which entered this region along the northern slope of Maud Rise.

Along the two westernmost meridional transects several branches with non-negligible near-surface velocities are associated with alternating eastward and westward components, indicating the existence of mesoscale eddy activity there. This leads to the assumption that the observed WDW cores are probably shed as eddies from the western flank of Maud Rise. This is corroborated by the studies of Bersch et al. (1992) and de Steur et al., 2007. Based on current meter data, Bersch et al. (1992) observed an anticyclone of WDW, which had cut off from the main body of WDW in the lee Maud Rise. In a recent study de Steur et al. (2007) used a isopycnic ocean model, which shows that eddies of alternating sign are formed from instability of jet-like flow structure, and are subsequently shed from the western flanks of the Rise.

Our study shows that WDW also enters the study area via the offshore part of the Antarctic Coastal Current. The Antarctic Slope Front (ASF), which is located around $69^{\circ} \mathrm{S}$ at $3^{\circ} \mathrm{E}$, defines the boundary between the cold, relatively fresh waters filling the Antarctic continental shelf and the warmer, more saline waters farther offshore (Jacobs, 1991). Owing to strong horizontal density gradients, the ASF is associated with a strong baroclinic, westward transport. However, our comparison of the baroclinic flow estimated following the geostrophic approach and the directly measured current indicates that the AntCC also has a strong barotropic transport component, what agrees with the finding of Núñez-Riboni and Fahrbach (2009).
Based on the comprehensive hydrographic analysis of the four meridional sections at $3^{\circ} \mathrm{E}, 0^{\circ}, 3^{\circ} \mathrm{W}$ and $6^{\circ} \mathrm{W}$ between 60 and $70^{\circ} \mathrm{S}$ during the Polarstern Cruise ANT-XXIII/2, Leach et al. (2010) show that a heterogeneous series of warm and salty cores entering the region from the east both north and south of Maud Rise $\left(65^{\circ} \mathrm{S}, 3^{\circ} \mathrm{W}\right)$ as well as with the Coastal Current, gradually merge and become more homogeneously distributed towards the west. The gradual reduction in the variance of potential temperature on isopycnals is indicative of isopycnic mixing processes downstream of Maud Rise.

Earlier estimates of the Weddell Gyre transport have varied between 17 Sv (Whitworth and Nowlin, 1987) and 97 Sv (Carmack and Foster, 1975) depending on the method chosen. In the absence of direct measurements Whitworth and Nowlin (1987) estimated a Gyre transport of $17 \mathrm{~Sv}$ relative to the deepest common depth between station pairs for the Greenwich Meridian section assuming a Sverdrupian balance. While the northern half of the gyre transports $16.1 \mathrm{~Sv}$ to the east, the southern half transports $17.2 \mathrm{~Sv}$ to the west. The latter was in perfect agreement with the overall relative westward transport of $17.3 \mathrm{~Sv}$ in the southern limb estimated by Klatt et al. (2005) from geostrophy. In our study, the net geostrophic transport referenced to the deepest common depth of neighboring station pairs across $3^{\circ} \mathrm{E}$ was $20.1 \mathrm{~Sv}$ during the summer survey and $16.9 \mathrm{~Sv}$ during the winter survey, and agrees well with the above cited estimates of Whitworth and Nowlin (1987) and Klatt et al. (2005).

We assume that the $3^{\circ} \mathrm{E}$ transect between $60^{\circ}$ and $70^{\circ} \mathrm{S}$ captures most of the transport of the southern limb of the Weddell Gyre, thus 
a

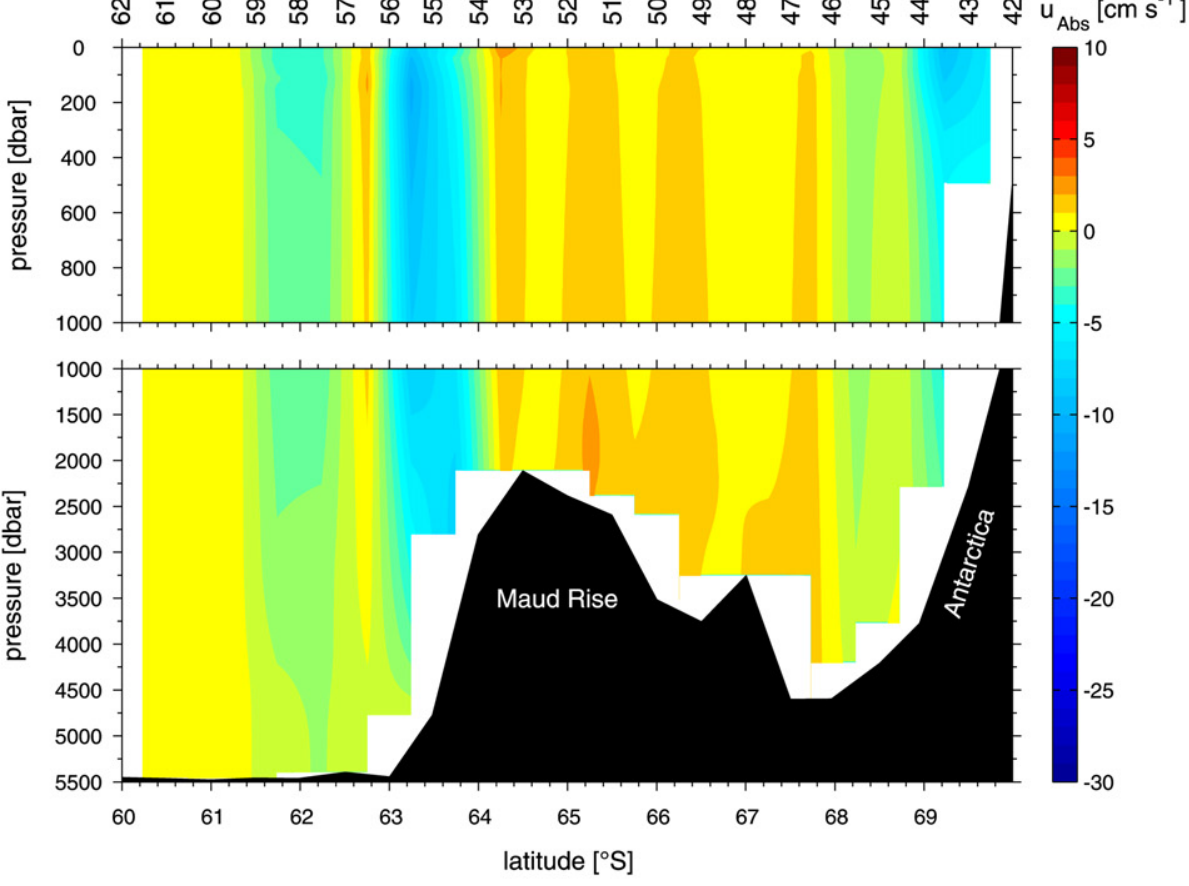

b
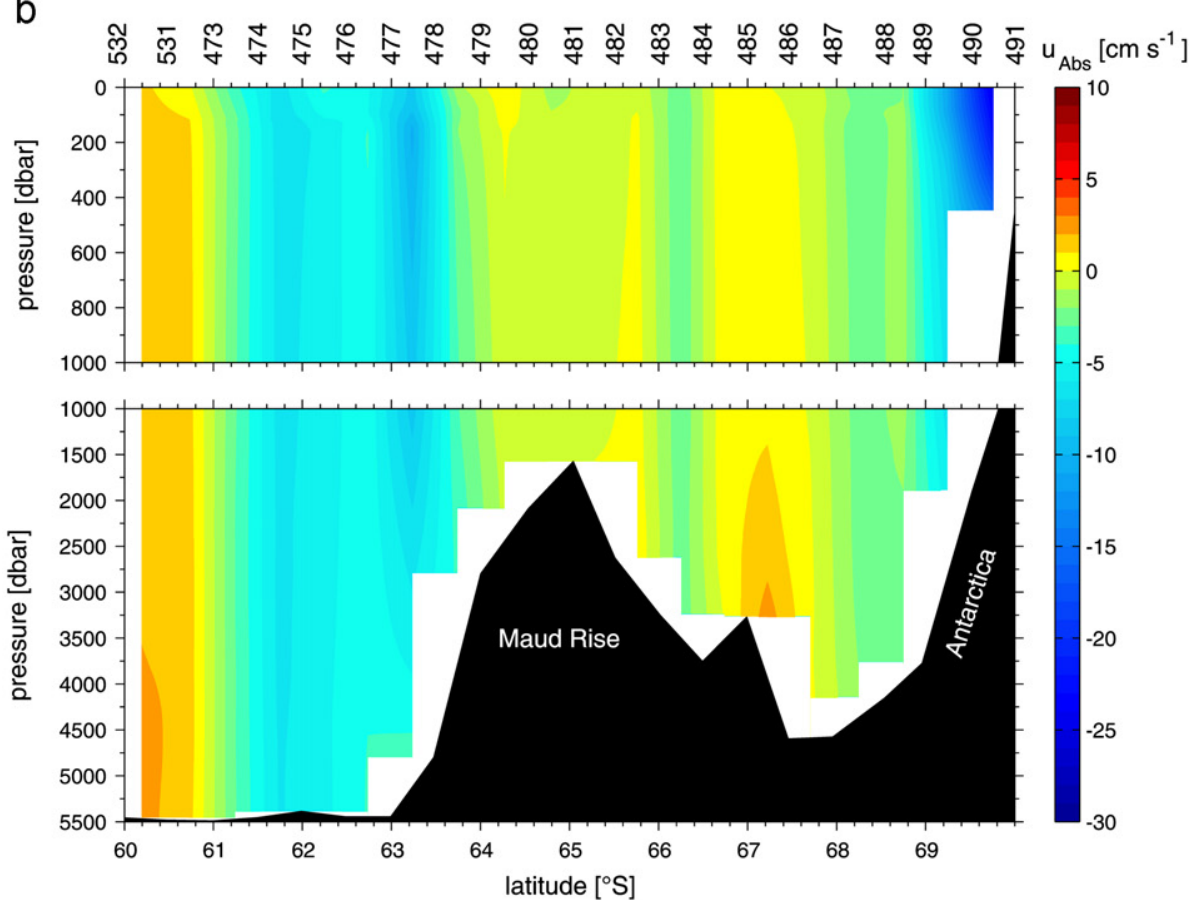

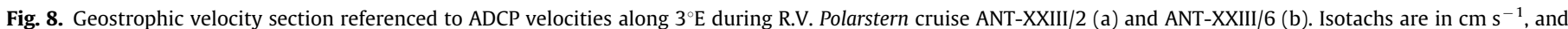
positive normal velocities represent eastward flow.

can be directly compared with the previous estimates of Whitworth and Nowlin (1987) and Klatt et al. (2005). This view is corroborated by the results of Beckmann et al. (1999). They used a circumpolar model to investigate the wind-driven and thermohaline circulation of the Weddell Gyre. The annual-mean transport stream function for year 20 in the Weddell Sea sector of the Southern Ocean yielded a pronounced and persistent double-cell structure in the Weddell Gyre with a maximum transport of $\sim 48 \mathrm{~Sv}$. Moreover, their Fig. 6 shows that almost all streamlines representing $42 \mathrm{~Sv}$ of the total $48 \mathrm{~Sv}$, which belong to the southwestward transport within the southern limb of the Weddell Gyre, run through the $3^{\circ}$ E section.
The difference between our transports estimates based on solely the baroclinic geostrophic flow and the flow adjusted to direct velocity measurements confirms, in agreement with Gordon et al. (1981) and Fahrbach et al. (1991), that all currents within the study area have a significant barotropic component, so that calculations based on the dynamic method alone underestimate the transport considerably. The first indications for considerable barotropic components in the Weddell Gyre circulation resulted from the study of Carmack and Foster (1975). They used geostrophic calculations adjusted to direct current measurements and estimated a transport of $97 \mathrm{~Sv}$. Gordon et al. (1981) calculated $76 \mathrm{~Sv}$ for the Sverdrup transport in the Weddell-Enderby 


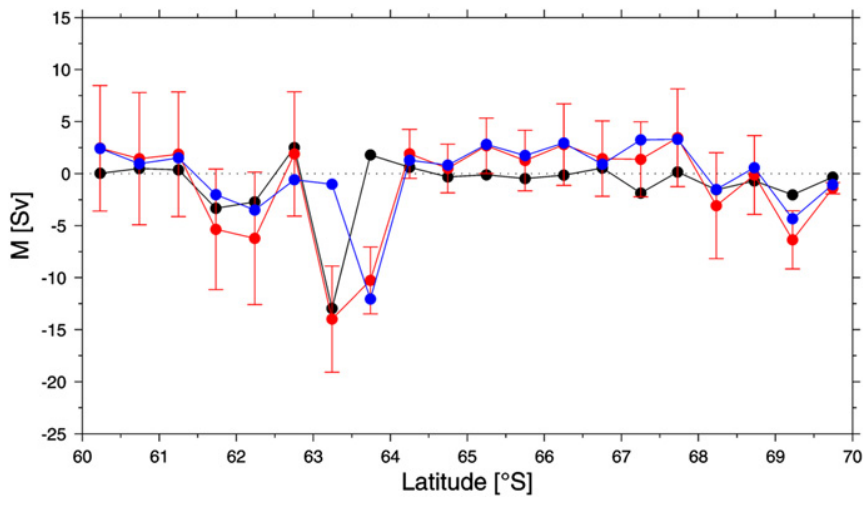

Fig. 9. Meridional distribution of the vertically integrated volume transports in $10^{6} \mathrm{~m}^{3} \mathrm{~s}^{-1}$ for each station pair at $3^{\circ} \mathrm{E}$ during R.V. Polarstern cruise ANT-XXIII/2: baroclinic transport (black line), barotropic transport (blue line) and total transport (red line). Error bars of the total transport result from standard deviations of the current used in estimating the transports and are dominated by the barotropic errors. (For interpretation of the references to color in this figure legend, the reader is referred to the web version of this article.)

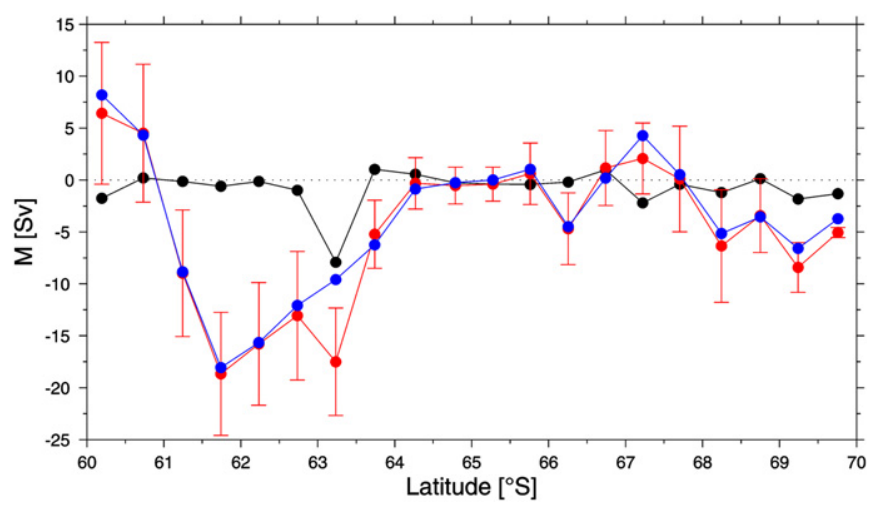

Fig. 10. Meridional distribution of the vertically integrated volume transports in $10^{6} \mathrm{~m}^{3} \mathrm{~s}^{-1}$ for each station pair at $3^{\circ} \mathrm{E}$ during R.V. Polarstern cruise ANT-XXIII/6 baroclinic transport (black line), barotropic transport (blue line) and total transport (red line). Error bars of the total transport result from standard deviations of the current used in estimating the transports and are dominated by the barotropic errors. (For interpretation of the references to color in this figure legend, the reader is referred to the web version of this article.)

Basin. Schröder and Fahrbach (1999) estimated on the basis of a combined CTD/ADCP dataset an eastward transport of $61 \mathrm{~Sv}$ and a westward return flow of $66 \mathrm{~Sv}$ in the southern limb of the Weddell Gyre across the Greenwich Meridian. The model results from Beckmann et al. (1999) yielded a pronounced and persistent double-cell structure in the Weddell Gyre with a maximum transport of $\sim 60 \mathrm{~Sv}$, in agreement with the observation of Schröder and Fahrbach (1999). Klatt et al. (2005) used current-meter observation from instruments moored at the Greenwich Meridian between 1996 and 2001 and estimated a mean volume transport for the whole period of $46 \mathrm{~Sv}$ to the east within the northern and $56 \mathrm{~Sv}$ to the west within the southern limb of the Weddell Gyre.

Although we had collected CTD and ADCP data also at more westerly longitudes, namely $0^{\circ} \mathrm{E}, 3^{\circ} \mathrm{W}$ and $6^{\circ} \mathrm{W}$, which in principle could reveal how the flow field continues downstream of $3^{\circ} \mathrm{E}$, we discarded calculating the absolute transport across those more western sections for the following reason.

While both $3^{\circ} \mathrm{E}$ transects consist of 21 deep CTD stations with a spacing of $56 \mathrm{~km}$, which permit to identify mesoscale structures, the sampling of the remaining transects with deep CTD stations is rather irregular and fragmentary as illustrated in the updated Figs. 1b and c.
Table 4

Eastward and northward baroclinic geostrophic transports referenced to the deepest common levels of neighboring station pairs and their divergences in the boxes encompassed across and between the four meridional sections. Transport estimates are in bold font and divergences are in Italian style.

\begin{tabular}{|c|c|c|c|c|c|c|c|}
\hline & $6^{\circ} \mathrm{W}$ & & $3^{\circ} \mathrm{W}$ & & $0^{\circ} \mathrm{E}$ & & $3^{\circ} \mathrm{E}$ \\
\hline \multirow[t]{2}{*}{$60^{\circ} \mathrm{S}$} & St. 104 & 0.1 & St. 103 & -1.3 & St. 63 & -0.2 & St. 62 \\
\hline & -2.3 & -0.8 & -4.9 & 0.0 & -1.6 & 0.1 & -2.4 \\
\hline \multirow[t]{2}{*}{$62^{\circ} \mathrm{S}$} & St. 108 & -1.7 & St. 99 & 2.0 & St. 67 & -1.1 & St. 58 \\
\hline & -4.9 & 0.1 & -2.1 & -0.1 & -12.9 & -0.2 & -11.4 \\
\hline \multirow[t]{2}{*}{$64^{\circ} \mathrm{S}$} & St. 112 & 1.0 & St. 95 & -8.7 & St. 71 & 0.6 & St. 54 \\
\hline & -3.9 & -0.1 & -7.0 & -1.4 & -3.4 & 1.6 & -0.3 \\
\hline \multirow[t]{2}{*}{$66^{\circ} \mathrm{S}$} & St. 116 & -2.0 & St. 91 & -3.7 & St. 76 & 2.1 & St. 50 \\
\hline & -2.3 & -0.5 & -3.0 & -2.0 & 0.7 & 0.4 & -1.4 \\
\hline \multirow[t]{2}{*}{$68^{\circ} \mathrm{S}$} & St. 120 & -2.2 & St. 87 & 0.6 & St. 79 & -0.3 & St. 46 \\
\hline & -4.9 & -1.5 & -4.9 & 2.4 & -2.8 & -2.3 & -4.6 \\
\hline $70^{\circ} \mathrm{S}$ & St. 125 & -0.7 & St. 83 & 0.3 & St. 82 & 0.2 & St. 42 \\
\hline Sum: & -18.3 & & -21.9 & & -20.0 & & -20.1 \\
\hline
\end{tabular}

The station distance along the western transects increases from $56 \mathrm{~km}$ over the Antarctic continental shelf to about $222 \mathrm{~km}$ in the deep Lazarev Sea. This irregular and rather large station spacing makes the estimation of absolute transports problematic, because the integration is sensitive to relatively small ADCP errors. In case of a station spacing of $220 \mathrm{~km}$ at $>5000 \mathrm{~m}$ depth the estimated error in the referencing method of $2 \mathrm{~cm} \mathrm{~s}^{-1}$ translates into a $22 \mathrm{~Sv}$ error in the transport between stations. However, if we refrain from adjustment to the barotropic component and consider only the baroclinic geostrophic transports across and between the four meridional sections between $6^{\circ} \mathrm{W}$ and $3^{\circ} \mathrm{E}$, these transports and their divergences in the boxes encompassed (Table 4) suggest a comparatively continuous westward geostrophic flow, which ranges between $18.3 \mathrm{~Sv}$ at $6^{\circ} \mathrm{W}$ and 21.9 Sv at $3^{\circ} \mathrm{W}$.

In our study, the net absolute volume transports across $3^{\circ} \mathrm{E}$ and between $60^{\circ}$ and $70^{\circ} \mathrm{S}$ result in a westward flow of $23.9 \pm 19.9 \mathrm{~Sv}$ in austral summer and $93.6 \pm 20.1 \mathrm{~Sv}$ in austral winter, which is similar to the range of the previous estimates mentioned above, but could also be indicative - despite the large range of uncertainty - of a significant seasonal difference. A strong seasonal cycle of the Weddell Gyre transport is seen in the numerical simulations obtained by Beckmann et al. (1999). The authors showed that the maximum Weddell Gyre transport varies between 52 and $69 \mathrm{~Sv}$, with the minimum in January and the maximum in July. This variation correlates closely with the area-averaged wind stress curl. They concluded that most of the seasonal change in transport can be explained as the direct effect of the wind forcing.

Using 6-hourly European Center for Medium-Range Weather Forecasts (ECMWF) wind data for the time period 2003-2007 we calculated the area-averaged wind stress curl for the region between $60^{\circ} \mathrm{W}$ and $40^{\circ} \mathrm{E}$ and between $70^{\circ} \mathrm{S}$ and $50^{\circ} \mathrm{S}$ (Fig. 11). Although this approach presents only a rough calculation, which does not take into account ice conditions and their possible effect on the drag coefficient, it reveals some interesting features. While the 5 -year mean area-averaged wind stress curl accounts for $-8.94 \times 10^{-8}$ $\mathrm{kg} \mathrm{m}^{-2} \mathrm{~s}^{-1}$, the wind stress curl has a temporary minimum of -6.97 to $-7.01 \times 10^{-8} \mathrm{~kg} \mathrm{~m}^{-2} \mathrm{~s}^{-1}$ during the summer survey (2005/2006) and a temporary maximum of -9.27 to $-9.32 \times 10^{-8}$ $\mathrm{kg} \mathrm{m}^{-2} \mathrm{~s}^{-1}$ during the winter survey (2006), if averaged over the duration of our measurements along the $3^{\circ} \mathrm{E}$-transect plus 30 or plus 90 days in advance. The area-averaged wind stress curl exhibits clear seasonal differences in the years 2003-2005 and 2007, with maxima during austral winter and minima during austral summer. The fiveyear mean winter and summer area-averaged wind stress curls accounts for -9.67 (30-days mean) and $-9.91 \times 10^{-8} \mathrm{~kg} \mathrm{~m}^{-2} \mathrm{~s}^{-1}$ (90-days mean), and for -8.38 and $-7.83 \times 10^{-8} \mathrm{~kg} \mathrm{~m}^{-2} \mathrm{~s}^{-1}$, 


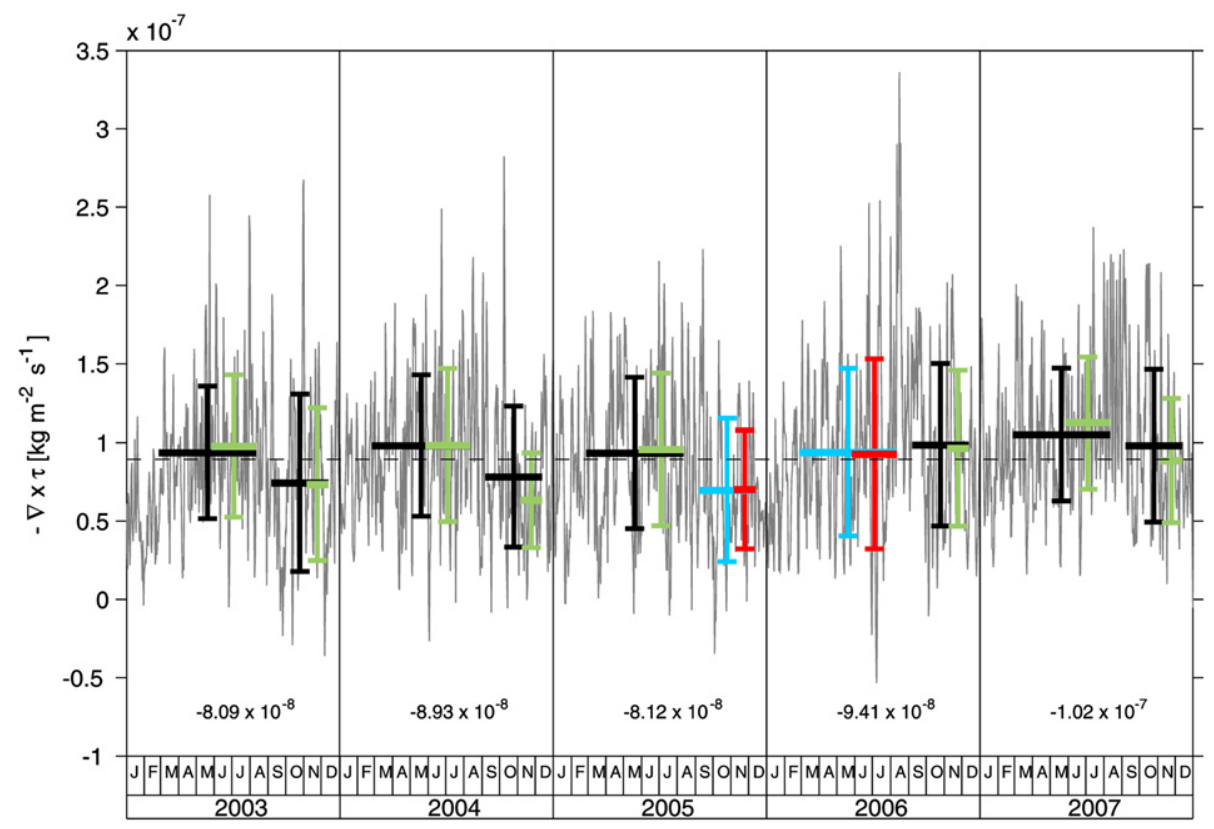

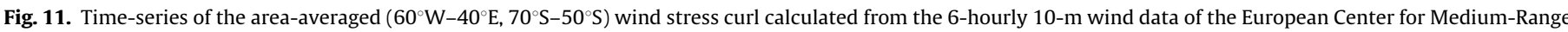

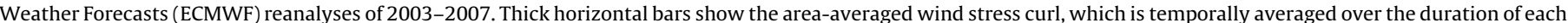

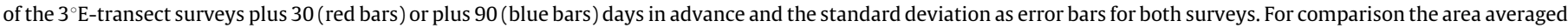

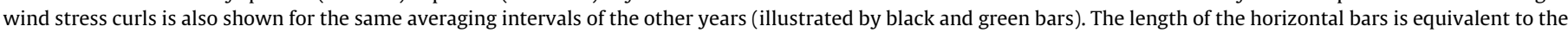

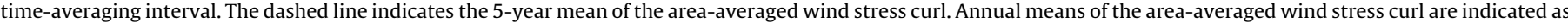
numbers in each of the 5-year boxes.

respectively. If we compare the five-year mean seasonal wintersummer differences of about -1.29 and $-2.09 \times 10^{-8} \mathrm{~kg} \mathrm{~m}^{-2} \mathrm{~s}^{-1}$ with the differences between the winter and the summer survey periods of about -2.3 and $-2.31 \times 10^{-8} \mathrm{~kg} \mathrm{~m}^{-2} \mathrm{~s}^{-1}$, we can conclude that the differences between the surveys are higher than the 5 -year mean seasonal differences, hence are enhanced by interannual changes. While the annual wind stress curl reveals only small differences between 2003 and 2005 (when the summer survey was performed), it increases to $-9.41 \times 10^{-8} \mathrm{~kg} \mathrm{~m}^{-2} \mathrm{~s}^{-1}$ in 2006 (when the winter survey took place) and to $1.02 \times 10^{-7} \mathrm{~kg} \mathrm{~m}^{-2} \mathrm{~s}^{-1} 2007$. Assuming a linear relationship between the forcing by the wind stress curl and the gyre circulation, approximately half of the significant seasonal transport variation of $29.8 \mathrm{~Sv}$ can be explained by differences in the gyre-scale wind forcing.

However, while the combination of the hydrographic and the highresolution ADCP measurements enable a qualitative investigation of the circulation, the estimation of absolute transports remains problematic, because of the sensitivity of the integration to relatively small ADCP errors. For example, assuming a spacing between stations of $56 \mathrm{~km}$ and a mean depth of greater than $4000 \mathrm{~m}$ results in an error in the referencing method of $2 \mathrm{~cm} \mathrm{~s}^{-1}$ which translates into a $4.5 \mathrm{~Sv}$ error in the transport between one station pair.

\section{Conclusions}

Two consecutive surveys conducted during austral winter 2005 and austral summer 2005/2006 enabled a hydrographic investigation of large parts of the southern limb of the Weddell Gyre. Although all the measurements presented bear the character of a snapshot taken during summer and winter, a number of generally valid conclusions about the water mass distribution and circulation in the southern limb of the Weddell Gyre can be drawn.

An important result is that in both seasons two gateways are apparent where masses of Warm Deep Water (WDW), recognizable by their temperature maximum, enter through the Lazarev Sea, (a) a probably topographically trapped westward and southwestward circulation around the northwestern edge of Maud Rise between $63^{\circ}$ and $63.5^{\circ} \mathrm{S}$ with maximum velocities of about $10 \mathrm{~cm} \mathrm{~s}^{-1}$ and (b) the Antarctic Coastal Current between $69^{\circ}$ and $70^{\circ} \mathrm{S}$, which is confined to the Antarctic continental shelf slope and is associated with maximum velocities of about $25 \mathrm{~cm} \mathrm{~s}^{-1}$. Owing to a significant barotropic component, the derived flow field shows an essentially columnar structure without any pronounced layer of no motion and confirms that calculations based on the dynamic method alone underestimate the transport considerably. The net absolute volume transports across the $3^{\circ} \mathrm{E}$ transects result in a westward flow of $23.9 \pm 19.9 \mathrm{~Sv}$ (austral summer) and $93.6 \pm 20.1 \mathrm{~Sv}$ (austral winter). The major contributions to the net absolute transport stem from the Maud Rise Jet $\left(63^{\circ}\right.$ to $\left.63.5^{\circ} \mathrm{S}\right)$, which accounts for $14.0 \pm 5.1 \mathrm{~Sv}$ and $17.5 \pm 5.2 \mathrm{~Sv}$, and from the AntCC $\left(69^{\circ}\right.$ to $\left.70^{\circ} \mathrm{S}\right)$, which accounts for $7.8 \pm 2.8$ and $13.5 \pm 2.5 \mathrm{~Sv}$ during the summer and the winter survey, respectively.

\section{Acknowledgments}

This work forms part of the joint project LAKRIS (Lazarev Sea Krill Study) funded by the German Federal Ministry of Education and Research (Bundesministerium für Bildung und Forschung, BMBF). Harald Rohr and Timo Witte contributed substantially to the collection of the hydrographic dataset. We gratefully acknowledge the support provided by the captain, officers and crew of the R.V. Polarstern. HL's participation in the cruise was funded by a grant from the Royal Society.

\section{References}

Bagriantsev, N.V., Gordon, A.L., Huber, B.A., 1989. Weddell Gyre: temperature maximum stratum. Journal of Geophysical Research 94, 8331-8334.

Bathmann, U., 2008. The expedition ANTARKTIS-XXIII/6 of the research vesse "Polarstern" in 2006. Berichte zur Polarforschung 580, 1-168. 
Beckmann, A., Hellmer, H.H., Timmermann, R., 1999. A numerical model of the Weddell Sea: large-scale circulation and water mass distribution. Journal of Geophysical Research 104, 23375-23391.

Bersch, M., Becker, G.A., Frey, H., Koltermann, K.-P., 1992. Topographic effects of the Maud Rise on the stratification of the Weddell Gyre. Deep-Sea Research 39, 303-331.

Carmack, E.C., Foster, T.D., 1975. On the flow of water out of the Weddell Sea. DeepSea Research 22, 711-724.

Cisewski, B., Strass, V.H., Prandke, H., 2005. Upper-ocean vertical mixing in the Antarctic Polar Frontal Zone. Deep-Sea Research II 52, 1087-1108.

Cisewski, B., Strass, V.H., Losch, M., Prandke, H., 2008. Mixed layer analysis of a mesoscale eddy in the Antarctic Polar Front Zone. Journal Geophysical Research 113, C05017. doi:10.1029/2007JC004372.

Cokelet, E.D., Schall, M.L., Dougherty, D.M., 1996. ADCP-referenced geostrophic circulation in the Bering Sea Basin. Journal of Physical Oceanography 26, 1113-1128.

Deacon, G.E.R., 1979. The Weddell Gyre. Deep-Sea Research 26A, 981-995.

de Steur, L., Holland, D.M., Muench, R.D., McPhee, M.G., 2007. The warm-wate "Halo" around Maud Rise: properties, dynamics and impact. Deep-Sea Research I $54,871-896$

Fahrbach, E., Knoche, M., Rohardt, G., 1991. An estimate of water mass transformation in the southern Weddell Sea. Marine Chemistry 35, 25-44.

Fahrbach, E., Rohardt, G., Schröder, M., Strass, V., 1994. Transport and structure of the Weddell Gyre. Annales Geophysicae 12, 840-855.

Firing, E., 1991. Acoustic Doppler current profiling measurements and navigation, WOCE Hydrographic Program Office Report. WHPO 91-9, WOCE Report. 68/91, $24 \mathrm{pp}$.

Foster, E., Carmack, E., 1976. Temperature and salinity structure in the Weddell Sea. Journal of Physical Oceanography 6, 36-44.

Gordon, A.L., 1967. Structure of Antarctic waters between $20^{\circ} \mathrm{W}$ and $170^{\circ} \mathrm{W}$. In: Bushnell, V.C. (Ed.), Antarctic Map Folio Series. Folio 6. American Geography Society, $10 \mathrm{pp}$.

Gordon, A.L., Martinson, D.G., Taylor, H.W., 1981. The wind-driven circulation in the Weddell-Enderby Basin. Deep-Sea Research 28A, 151-163.

Gordon, A.L., Huber, B.A., 1990. Southern Ocean Winter Mixed Layer. Journal of Geophysical Research 95, 11655-11672.

Gordon, A.L., Huber, B.A., 1995. Warm Weddell Deep Water west of Maud Rise. Journal of Geophysical Research 100, 13747-13753.

Gouretski, V.V., Danilov, A.I., 1993. Weddell Gyre: structure of the eastern boundary. Deep-Sea Research I 40, 561-582.

Jacobs, S.S., 1991. On the nature and significance of the Antarctic Slope front. Marine Chemistry 35, 9-24.
Johns, E., Watts, D.R., Rossby, H.T., 1989. A test of geostrophy in the Gulf Stream. Journal of Geophysical Research 94, 3211-3222.

Joyce, T.M., 1989. On in situ calibration of shipboard ADCPs. Journal of Atmospheric and Oceanic Technology 6, 169-172.

Klatt, O., Fahrbach, E., Hoppema, M., Rohardt, G., 2005. The transport of the Weddell Gyre across the prime meridian. Deep-Sea Research II 52, 513-528.

Leach, H., Strass, V.H., Cisewski, B., 2010. Modification by lateral mixing of the warm deep water entering the Weddell Sea in the Maud Rise region. Ocean Dynamics, doi:10.1007/s10236-010-0342-y.

Lynn, R.J., Reid, J.L., 1968. Characteristics and circulation of deep and abyssal waters. Deep-Sea Research 15, 577-598.

McPhee, M.G., Ackley, S.F., Guest, P., Huber, B.A., Martinson, D.G., Morison, J.H. Muench, R.D., Padman, L., Stanton, T., 1996. The Antarctic flux zone experiment. Bulletin of the American Meteorological Society 77, 1221-1232.

Muench, R.D., Morison, J.H., Padman, L., Martinson, D., Schlosser, P., Huber, B., Hohmann, R., 2001. Maud Rise revisited. Journal of Geophysical Research 106, 2423-2440.

Núñez-Riboni, I., Fahrbach, E., 2009. Seasonal variability of the Antarctic Coastal Current and its driving mechanisms in the Weddell Sea. Deep Sea Research I 56, 1927-1941.

Orsi, A.H., Nowlin Jr., W.D., Whitworth III, T., 1993. On the circulation and stratification of the Weddell Gyre. Deep-Sea Research I 40, 169-203.

Padman, L., Fricker, H.A., Coleman, R., Howard, S., Erofeeva, L., 2002. A new tide model for the Antarctic ice shelves and seas. Annals of Glaciology 34, 247-254.

Pickart, R.S., Lindstrom, S., 1994. A comparison of techniques for referencing geostrophic velocities. Journal Atmospheric Oceanic Technology 11, 814-824.

Pollard, R.T., Read, J., 1989. A method of calibrating ship-mounted acoustic Doppler profilers and the limitations of gyro compasses. Journal of Atmospheric and Oceanic Technology 6, 859-865.

Pond, S., Pickard, G.L., 1983. Introductory Dynamical Oceanography, 2nd Edition Pergamon Press, Oxford, 329 pp.

Schröder, M., Fahrbach, E., 1999. On the structure and the transport of the eastern Weddell Gyre. Deep-Sea Research II 46, 501-527.

Sirevaag, A., McPhee, M.G., Morison, J.H., Shaw, W.J., Stanton, T.P., 2010. Wintertime mixed layer measurements at Maud Rise, Weddell Sea. Journal of Geophysical Research, 115. doi:10.1029/2008JC005141.

Strass, V., 2007. The expedition ANTARKTIS-XXIII/2 of the research vessel "Polarstern" in 2005/2006. Berichte zur Polarforschung 568, 1-138.

Whitworth III, T., Nowlin, W.D., 1987. Water masses and currents of the Southern Ocean at the Greenwich Meridian. Journal of Geophysical research 92, 6462-6476. 